\title{
\#USGS $\approx$
}

Literature Review for Candidate Chemical Control Agents for Nonnative Crayfish

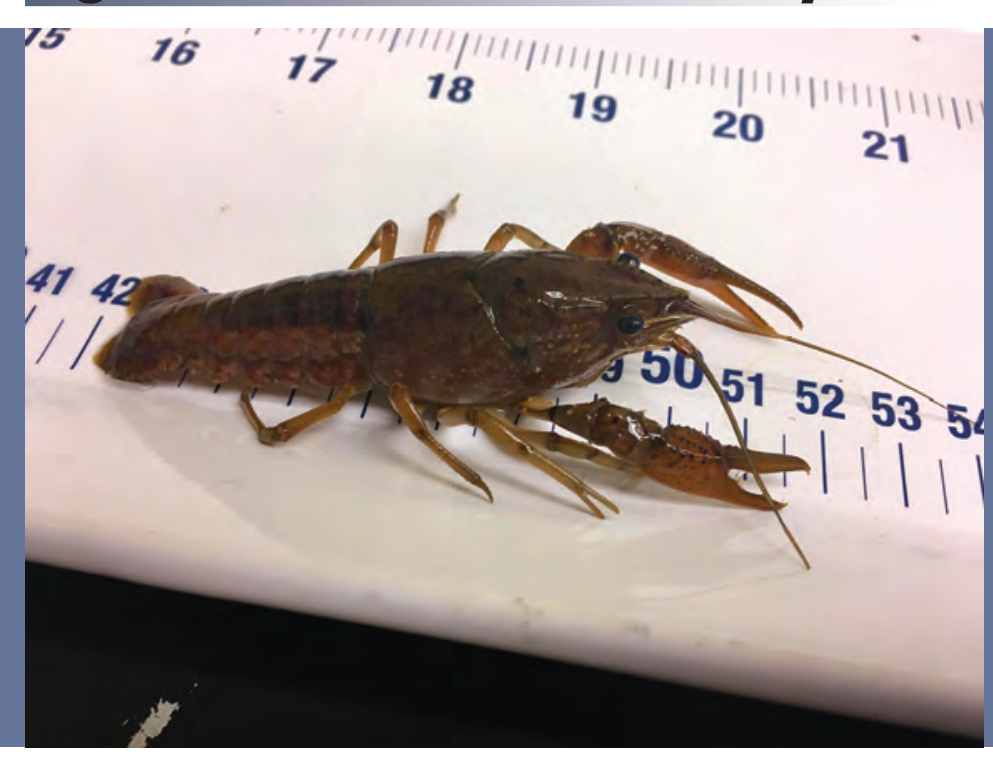

WVIVITIN 4ting

Open-File Report 2021-1048

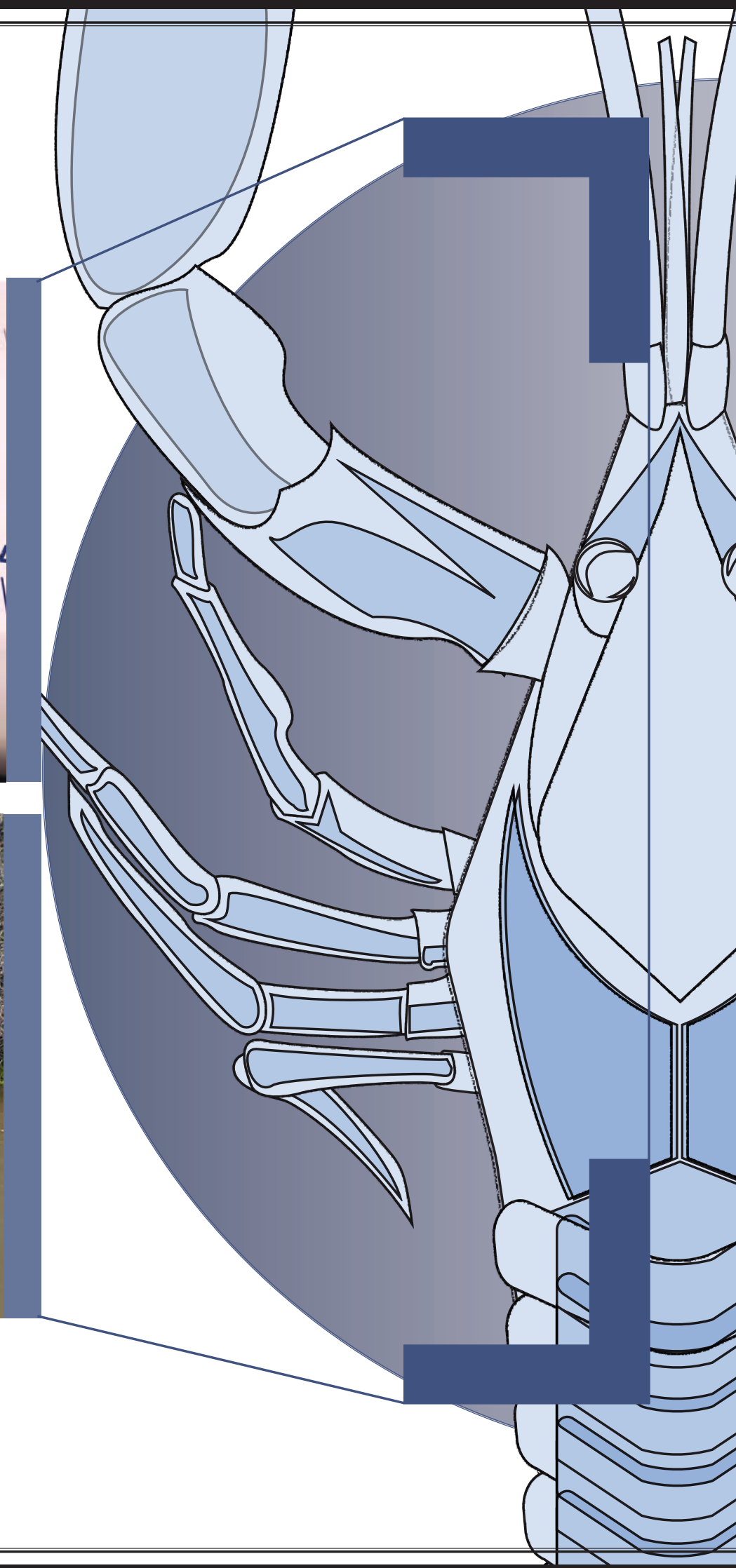

U.S. Department of the Interior U.S. Geological Survey 
Front cover. Crayfish Illustration by David Bruce, U.S. Geological Survey, Science Publishing Network. Upper inset photograph of Procambarus clarkii (red swamp crayfish) by Justin Smerud, biologist, U.S. Geological Survey. Lower inset photograph of gnawed tree in the Agashashok River, Alaska, by Michael Carey, research fish biologist, U.S. Geological Survey.

Back cover. Background photograph of Sugar Creek, Indiana, by Megan Saksa, hydrologist, U.S. Geological Survey. Upper inset photograph of Pole Bridge Creek, Georgia, by Alan Cressler, hydrologic technician, U.S. Geological Survey. Lower inset photograph of Kettle Lake, Colorado, by Laura Hempel, hydrologist, U.S. Geological Survey. 


\section{Literature Review for Candidate Chemical Control Agents for Nonnative Crayfish}

By Justin R. Schueller, Justin R. Smerud, Kim T. Fredricks, and Joel G. Putnam

Prepared in cooperation with the U.S. Fish and Wildlife Service

Open-File Report 2021-1048 


\section{U.S. Geological Survey, Reston, Virginia: 2021}

For more information on the USGS - the Federal source for science about the Earth, its natural and living resources, natural hazards, and the environment—visit https://www.usgs.gov or call 1-888-ASK-USGS.

For an overview of USGS information products, including maps, imagery, and publications, visit https://store.usgs.gov/.

Any use of trade, firm, or product names is for descriptive purposes only and does not imply endorsement by the U.S. Government.

Although this information product, for the most part, is in the public domain, it also may contain copyrighted materials as noted in the text. Permission to reproduce copyrighted items must be secured from the copyright owner.

Suggested citation:

Schueller, J.R., Smerud, J.R., Fredricks, K.T., and Putnam, J.G., 2021, Literature review for candidate chemical control agents for nonnative crayfish: U.S. Geological Survey Open-File Report 2021-1048, 32 p., https://doi.org/ 10.3133/ofr20211048.

ISSN 2331-1258 (online) 


\section{Financial Acknowledgment}

Funding for this literature review was provided by the U.S. Fish and Wildlife Service interagency agreement 4500087259 . 



\section{Contents}

Financial Acknowledgment............................................................................................................ii

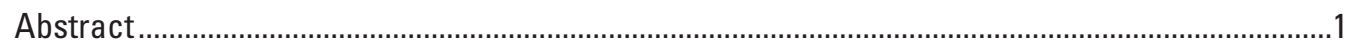

Introduction

Methods

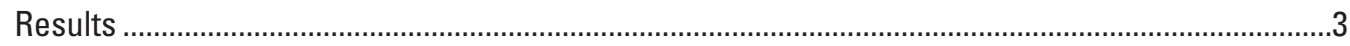

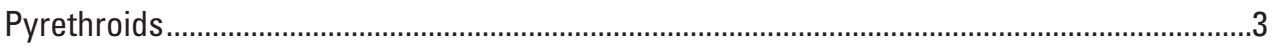

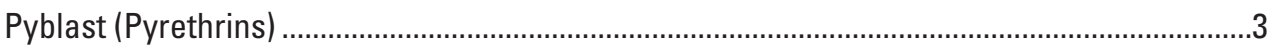

Aquatic Toxicity .....................................................................................................

Environmental Persistence .........................................................................................

Registration Data Gaps for Pyblast............................................................................

Type-1 Pyrethroids (Primarily Permethrin) ………….....................................................................

Aquatic Toxicity ....................................................................................................

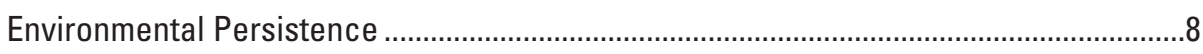

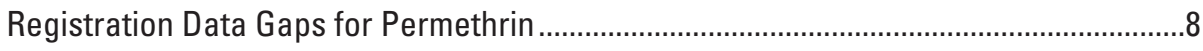

Type-2 Pyrethroids (Primarily Cyfluthrin) …………..........................................................

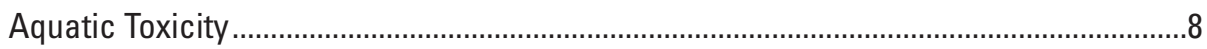

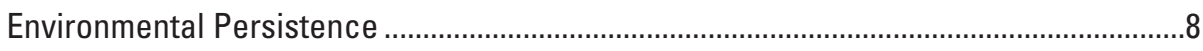

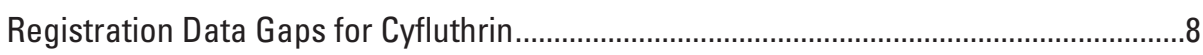

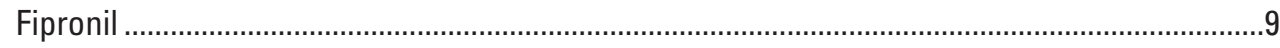

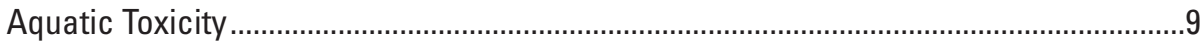

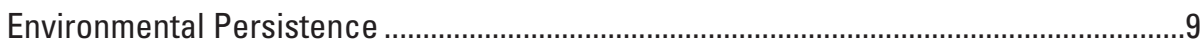

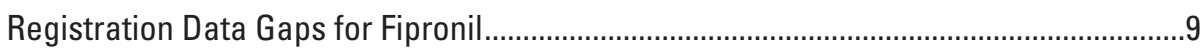

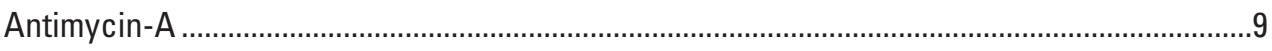

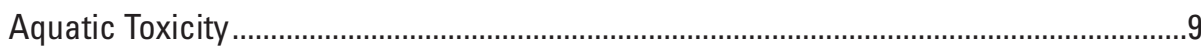

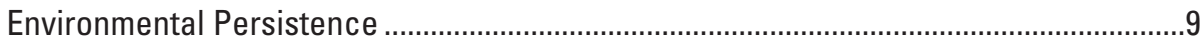

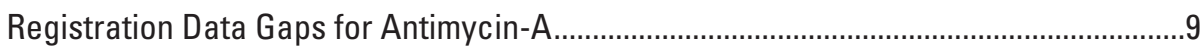

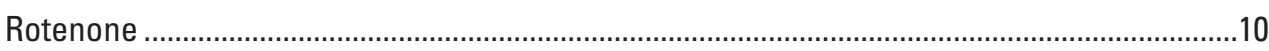

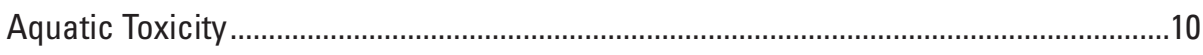

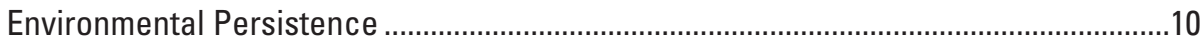

Registration Data Gaps for Rotenone ..........................................................................

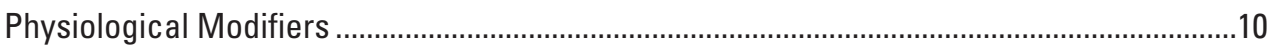

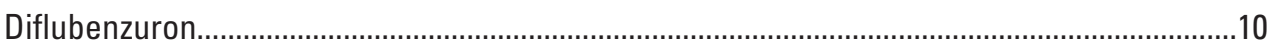

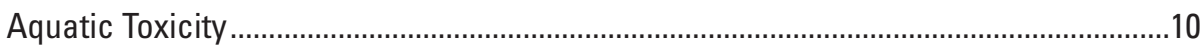

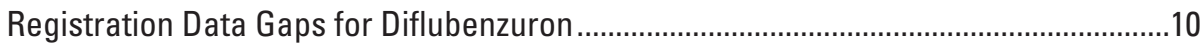

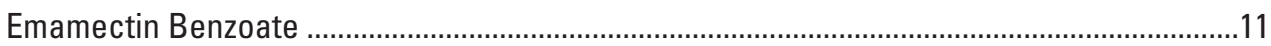

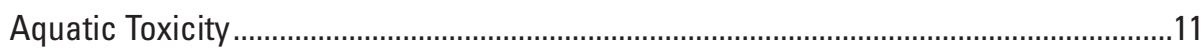

Environmental Persistence ..............................................................................................11

Registration Data Gaps for Emamectin Benzoate .........................................................11

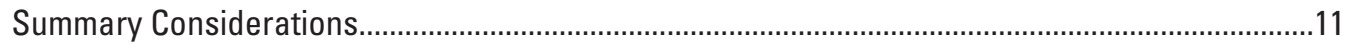

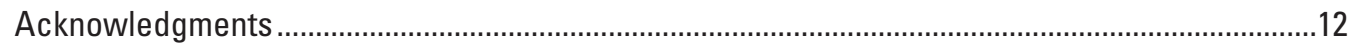

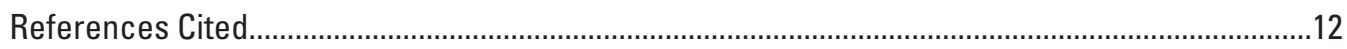

Appendix 1. Search Terms for the "Literature Review for Candidate Control Agents for Nonnative Crayfish" ....................................................................................................18

Appendix 2. Chemical Properties and Toxicity Data as Determined from the "Literature Review for Candidate Control Agents for Nonnative Crayfish" .........................................20 


\section{Tables}

1. The U.S. Environmental Protection Agency guideline number for Section 835fate, transport and transformation, type of data requirement.

2. The U.S. Environmental Protection Agency guideline number for section 850 ecological effects, type of data requirement.

3. The U.S. Environmental Protection Agency guideline number for Section 870health effects, type of data requirement.

4. The U.S. Environmental Protection Agency guideline number for Section 875 occupational and residential exposure, type of data requirement

\section{Conversion Factors}

International System of Units to U.S. customary units

\begin{tabular}{lcl}
\hline \multicolumn{1}{c}{ Multiply } & By & \multicolumn{1}{c}{ To obtain } \\
\hline centimeter $(\mathrm{cm})$ & Length & inch (in.) \\
millimeter $(\mathrm{mm})$ & 0.3937 & inch (in.) \\
meter $(\mathrm{m})$ & 0.03937 & foot $(\mathrm{ft})$ \\
kilometer $(\mathrm{km})$ & 3.281 & mile $(\mathrm{mi})$ \\
kilometer $(\mathrm{km})$ & 0.6214 & mile, nautical (nmi) \\
meter $(\mathrm{m})$ & 0.5400 & yard (yd) \\
\hline & 1.094 & \\
\hline liter $(\mathrm{L})$ & Volume & ounce, fluid (fl. oz) \\
liter $(\mathrm{L})$ & 33.81402 & pint (pt) \\
liter $(\mathrm{L})$ & 2.113 & quart (qt) \\
liter $(\mathrm{L})$ & 1.057 & gallon (gal) \\
liter $(\mathrm{L})$ & 0.2642 & cubic inch (in $\left.{ }^{3}\right)$ \\
\hline & 61.02 & \\
\hline microgram $(\mu \mathrm{g})$ & \multicolumn{1}{c}{ Mass } & ounce, avoirdupois (oz) \\
milligram $(\mathrm{mg})$ & $3.5274 \times 10-8$ & ounce, avoirdupois $(\mathrm{oz})$ \\
gram $(\mathrm{g})$ & $3.527 \times 10-5$ & ounce, avoirdupois $(\mathrm{oz})$ \\
kilogram $(\mathrm{kg})$ & 0.03527 & pound avoirdupois $(\mathrm{lb})$ \\
\hline
\end{tabular}

Temperature in degrees Celsius $\left({ }^{\circ} \mathrm{C}\right)$ may be converted to degrees Fahrenheit $\left({ }^{\circ} \mathrm{F}\right)$ as follows: ${ }^{\circ} \mathrm{F}=\left(1.8 \times{ }^{\circ} \mathrm{C}\right)+32$.

\section{Supplemental Information}

Concentrations of chemical constituents in water are given in either milligrams per liter ( $\mathrm{mg} / \mathrm{L}$ ) or micrograms per liter $(\mu \mathrm{g} / \mathrm{L})$.

Absorption values of chemicals to sediment are given in micrograms per gram $(\mu \mathrm{g} / \mathrm{g})$.

Molecular weight values of chemicals are given in grams per mole $(\mathrm{g} / \mathrm{mol})$. 


\section{Abbreviations}

$\mathrm{LC}_{50} \quad$ lethal concentration to produce fifty percent mortality in test species

EPA United States Environmental Protection Agency 



\title{
Literature Review for Candidate Chemical Control Agents for Nonnative Crayfish
}

\author{
By Justin R. Schueller, Justin R. Smerud, Kim T. Fredricks, and Joel G. Putnam
}

\section{Abstract}

Nonnative crayfish are an immediate and pervasive threat to aquatic environments and their biodiversity. Crayfish control can be achieved by physical methods, water chemistry modification, biological methods, biocidal application, and application of crayfish physiology modifiers. The purpose of this report is to identify suitable candidates for potential control of nonnative crayfish through a comprehensive literature review. This review focuses on control methods, specifically on the available data to support registration of a crayfish pesticide. The literature search resulted in 28,058 documents, which were searched to determine if they contained information on physical, chemical, biological, and (or) biocidal approaches to control crayfish. Pesticides directly toxic to crayfish in this literature review include: pyrethroids (natural pyrethrins and synthetic), fipronil, mirex, antimycin-A, and rotenone. Some chemicals, such as diflubenzuron and emamectin benzoate, alter crayfish physiology resulting in a lower pesticide dose needed to control crayfish. Environmental damage, application rate, exposure duration, nontarget effects, environmental persistence, and registration data gaps were used as criteria to define which pesticides are potentially selective to crayfish, along with which have the greatest amount of data to support registration by the U.S. Environmental Protection Agency.

Synthetic pyrethroids were identified as the most likely candidate to be developed into a crayfish pesticide. A type-2 synthetic pyrethroid, cyfluthrin, has the greatest potential for eradicating nonnative crayfish. Although other invertebrate species will be negatively affected at the concentrations required for crayfish control, compared with other pyrethroids and other potential control chemicals, cyfluthrin offers rapid ecosystem recovery due to being more selective, having fewer effects on native fish, and having a short aquatic persistence. Cyfluthrin also has few data gaps for U.S. Environmental Protection Agency registration purposes.

\section{Introduction}

Nonnative crayfish are an immediate and pervasive threat to aquatic environments and are listed under the Species Action Framework as species that pose a significant threat to biodiversity and catastrophic regime shift (Hill and Lodge, 1999; McCarthy, 2006; Gladman and others, 2009; Matsuzaki and others, 2009; Hansen and others, 2013; Twardochleb and others, 2013; James and others, 2015). Nonnative crayfish can reduce aquatic plant diversity by consuming shoreline vegetation (Schuytema, 1977); decrease length and growth of certain macrophytes (Chambers and others, 1990); and cause declines in native fish, amphibian, and invertebrate species populations (Schuytema, 1977; Bills and Marking, 1988; Chambers and others, 1990; Hanson and others, 1990; Gamradt and others, 1997; Dorn and Mittelbach, 2004; Griffiths and others, 2004; Kerby and others, 2005). Additionally, lacustrine and riverine environments contain endemic and rare crayfish species that contribute to ecosystem biodiversity (Griffiths and others, 2004) and that are threatened by the introduction of nonnative crayfish (Kerby and others, 2005). At least ten crayfish species have been introduced across the United States and four are considered widespread nonnative species (https://nas.er.usgs.gov/): Procambarus clarkii (red swamp crayfish), Faxonius rusticus (rusty crayfish; previously Orcenectes rusticus), Orcenectes virilis (virile crayfish), and Pasifastacus lenusculus (signal crayfish). Several approaches to nonnative crayfish control have been explored including physical removal, alterations to habitat, biological controls, and chemical controls.

Attempts to eradicate nonnative crayfish have included habitat destruction, establishment of barriers, and trapping. Habitat destruction typically reduces populations of crayfish (Peay, 2001) but does not eradicate populations and affects endemic and rare species (Stebbing and others, 2014). Barriers are designed to prevent or slow the spread of crayfish into new areas but are not successful for permanent control (Peay 2001; Hyatt, 2004). Trapping can remove large numbers of nonnative crayfish but is very labor intensive, does not eradicate populations, and can have size and sex catch bias (Bills and Marking, 1988; Holdich and Gherardi, 1999; Peay and others, 2006; Stebbing and others, 2014; O'Reilly, 2015; Longshaw and Stebbing, 2016). 
Modifications to water quality has been identified as a nonnative species management strategy. By adjusting ammonia, $\mathrm{pH}$, and oxygen concentration, nonnative species can be potentially controlled without persisting negative environmental effects (Hyatt, 2004). However, altered water chemistry may also negatively affect nontarget populations. Adjusting water $\mathrm{pH}$ and ammonia can cause nontarget organism mortality (Tarazona and others, 1987; Bergerhouse, 1992; Mummert and others, 2003). Deoxygenation can be used in tandem with a pesticide to control crayfish; deoxygenation stimulates crayfish to leave their burrows, exposing the crayfish to higher chemical concentrations (Peay 2001; Peay and others, 2006). Carbon dioxide, a pesticide approved by the U.S. Environmental Protection Agency (EPA) for control of other aquatic nuisances (Cupp and others, 2020), causes avoidance behavior in several fish species (Donaldson and others 2016) and is effective in altering behavior of nonnative crayfish in water (Bierbower and Cooper, 2010; Fredricks and others, 2020). Concentrations of carbon dioxide required to alter crayfish behavior may cause nontarget organism mortality (Cupp and others, 2020). Methods to modify water quality to control nonnative crayfish would require further research for EPA registration. Also, most states have water quality standards for $\mathrm{pH}$ and ammonia that cannot be violated, and these standards may not allow for crayfish control using $\mathrm{pH}$ and ammonia or may require coordination with state agencies to utilize these types of control technique.

Biological controls (such as parasites, pathogens, and predators) also have potential to be used as invasive species control tools (Meyer and Fourdrigniez, 2011; Gherardi and others, 2011). Parasites have reduced crayfish populations (Sargent and others, 2014; Imhoff and others, 2012). Pathogens such as fungi, bacteria, and viruses have been linked with selective crayfish mortality and may be useful to control their populations (Alderman, 1996; Aquiloni and others, 2011; Freeman and others, 2010; McMahon and others, 2013; Martin-Torrijos and others, 2019).) The use of biological controls such as parasites and disease would require substantial research for registration for crayfish control.

Predation to control populations of invasive species is dependent on habitat, water quality, and management of predators but may improve the overall success of control (Hein and others, 2007; Freeman and others, 2010). The use of biological controls such as predation require additional research to identify the potential ecological effects of introducing a new species or disease.

Many existing integrated pest management strategies used to control nuisance species rely on the use of chemicals (Peay, 2001; Kasai and others, 2016). These chemicals (pesticides) may play an important role in nonnative crayfish control, but unfortunately no chemical has been registered for use in the United States to control crayfish. Several chemicals (such as pyrethroids, fipronil, diflubenzuron, mirex, antimycin-A, rotenone, and emamectin benzoate [avermectin]) have been reported to kill crayfish and may have existing data that could be used to support registration. The objective of this report is to identify chemicals for which data on (1) selectivity to crayfish and (2) pesticide registration exist that together warrant further research to develop as a nonnative crayfish pesticide. We completed an intensive literature review for pyrethrins, pyrethroids, fipronil, diflubenzuron, mirex, antimycin-A, rotenone, and avermectin to determine their potential to be registered through EPA as a crayfish-specific pesticide.

\section{Methods}

We performed a preliminary literature search for chemicals that could be rapidly developed into crayfish pesticides and identified eight chemicals as potential crayfish pesticides. Then we completed a comprehensive literature search focused on the potential to register pyrethrins, pyrethroids, fipronil, diflubenzuron, mirex, antimycin-A, rotenone, and avermectin as nonnative crayfish pesticides. Our comprehensive search focused on chemical selectivity to crayfish and requirements for EPA registration as a potential pesticide. We searched the Web of Science and Scopus databases using multiple search terms related to selectivity and registration (appendix 1). Search terms were developed from the data requirements for pesticide registration (U.S. Office of the Federal Register [USOFR], 2017). Information identified in the literature search was reviewed for potential to fill identified registration data gaps. We screened through Reregistration Eligibility Decisions for each chemical. The Master Record Identifiers (MRID) was reported when it existed for a specific guideline (guidelines from the US Code of Federal Regulations Title 40:Protection of Environment, Chapter 1:Environmental Protection Agency, Subchapter E:Pesticide Programs, Part 158:Data Requirements for Pesticides, Subparts: F:Toxicology, G: Ecological Effects, $\mathrm{K}$ : Human Exposure, and N: Environmental Fate).

We screened EPA's ECOTOX Knowledgebase (https://cfpub.epa.gov/ecotox/) to identify if the chemicals were toxic to crayfish and nontarget species to assess if levels of toxicity were similar (appendix 2). We searched the database for pyrethrins (Pyblast, and pyrethrins) type-1 pyrethroids (permethrin), type-2 pyrethroids (cyfluthrin), fipronil, diflubenzuron, mirex, antimycin-A, rotenone, and emamectin benzoate (avermectin). Pyrethrin was used as a surrogate for Pyblast. Permethrin was selected as a representative from the pyrethrin type-1 synthetic pyrethroid data and cyfluthrin was selected as a representative for the pyrethrin type-2 synthetic pyrethroid data. Data from the ECOTOX database were downloaded on April 25, 2019.

The preliminary search indicated mirex as a potential crayfish pesticide. Mirex is an organochloride that was used to control ants. Its use was prohibited by EPA in 1978 and Stockholm Convention on Persistent Organic Pollutants due to its environmental persistence and bioaccumulation concerns (Eisler, 1985). Mirex is not included in the results section because the actions by EPA and the Stockholm Convention make it unlikely to be registered as a crayfish control tool. 


\section{Results}

Potential nonnative crayfish pesticides (including pyrethrins, pyrethroids, fipronil, antimycin-A, rotenone, diflubenzuron, and emamectin benzoate) are discussed in the following sections. Previous uses, crayfish toxicity, nontarget toxicity, and environmental fate data are reviewed. EPA registration data gaps, and the potential for the reviewed literature filling these data gaps are discussed. Tables 1-4 contain a list of data requirements (located in 40 CFR Part 158 [USOFR, 2017]) for pesticides, if there are data accepted by the EPA for the requirement, and if relevant data were identified to potentially fill an identified data gap.

\section{Pyrethroids}

The insecticide Pyblast is produced naturally by the flower Chrysanthemum cinerariefolium (Matsuda, 2011). Pyblast (pyrethrins) is separated from the synthetic pyrethroids based on their environmental persistence and toxicity. Pyrethroids were separated into two categories: type- 1 and type-2. Type-1 pyrethroids lack an $\alpha$-cyano group (Wolansky and others, 2006), and produce repetitive nerve discharge in target organisms (Palmquist and others, 2012).

\section{Pyblast (Pyrethrins)}

Pyblast, natural pyrethrins, are separated from synthetic pyrethroids based on differences in environmental persistence and toxicity.

\section{Aquatic Toxicity}

Pyblast has been used to control nonnative crayfish is Scotland and Italy (Peay and others, 2006; Cecchinelli and others, 2012; O'Reilly, 2015). Much of the crayfish toxicity data available for Pyblast is from signal crayfish (table 2.1). Pyblast seems more toxic to hatchlings (less than 1-year-old crayfish) than adults (O'Reilly 2015; table 2.1). Crayfish evacuated water when Pyblast was applied (Hyatt, 2004). Treatment efficacy might be increased if the area surrounding the waterbody is treated, because crayfish placed on Pyblast treated ground were dead within 1 hour (Hyatt, 2004). It is important to note that Pyblast loses much of its terrestrial application efficacy after one hour (Hyatt, 2004).

The concentration of Pyblast needed for complete adult crayfish mortality is greater than concentrations likely to cause significant mortality to other aquatic invertebrates and fish species (table 2.2). The use of Pyblast may affect other aquatic organisms such as amphibians. The life history of amphibians suggests that they may recolonize treated ponds through overland movements from refugia (Hall and others, 2013). Pyblast has low mammalian and avian toxicity (Peay and others, 2006).

\section{Environmental Persistence}

Literature values for the environmental persistence of Pyblast varies. Peay and others (2006) report a half-life of 48 hours in water compared to the environmental persistence varying from hours to several days prior to degradation reported by Gerberding (2003). Hyatt (2004) reported even more rapid degradation with significant chemical losses within an hour after application. Photodegradation and sediment binding occur at extremely rapid rates (O'Reilly, 2015). Pyblast has a strong binding affinity to sediment where microbial degradation rapidly occurs (Gerberding, 2003; Todd and others, 2003). It has not been determined to biomagnify (Peay and others, 2006; O’Reilly, 2015).

\section{Registration Data Gaps for Pyblast}

Data gaps for Pyblast are identified in tables 1-4. Pyrethrin is registered with EPA as a terrestrial insecticide. Potential data have been reported for guideline 835.1230adsorption/desorption (Antonius and others, 2011). No relevant data were identified for: guideline 835.1230-adsorption/ desorption (batch equilibrium) except as noted in tables $1-4$. The remaining data gaps include: guidelines 835.2240 photodegradation in water, 835.6200-aquatic (sediment) field dissipation, 850.1300-aquatic invertebrate life cycle (freshwater), 850.1400-fish early-life stage (freshwater), 850.4100 -seedling emergence, 850.4150 -vegetative vigor, and 850.4400 -aquatic plant growth.

\section{Type-1 Pyrethroids (Primarily Permethrin)}

Type-1 pyrethroids (primarily permethrin) lack an $\alpha$-cyano group (Wolansky and others, 2006) and produce repetitive nerve discharge in target organisms (Palmquist and others, 2012).

\section{Aquatic Toxicity}

The available toxicity data for type- 1 pyrethroids for crayfish are primarily for permethrin (table 2.3). Permethrin caused complete mortality of signal crayfish after a 1-hour laboratory exposure at 6 micrograms per liter $(\mu \mathrm{g} / \mathrm{L}$; (Peay, 2001). Type-1 pyrethroids have similar toxicity to crayfish and other aquatic invertebrates thus environmental applications at rates lethal to crayfish would likely be lethal to most other aquatic invertebrates present. Some species of fish are less susceptible than crayfish to permethrin, whereas others are equally susceptible (table 2.4), indicating the potential for effects to some fish species from permethrin applications with permethrin at concentrations needed to eradicate crayfish. Pimephales promelas (Fathead minnow) exposed to the type-1 pyrethroid esfenvalerate at 0.455 and $1.142 \mu \mathrm{g} / \mathrm{L}$ displayed impaired swimming and feeding behaviors even after being transferred to clean water, suggesting that some organisms 
Table 1. The U.S. Environmental Protection Agency guideline number for Section 835-fate, transport and transformation, type of data requirement. A "Yes" indicates there are data accepted by the U.S. Environmental Protection Agency.

[MRID, Master Record Identifier (indicates the most recent registration has been approved); N/A, no data available; a number indicates the quantity of journal articles that may provide support for approval of that guideline.]

\begin{tabular}{|c|c|c|c|c|c|c|c|c|c|}
\hline \multirow{2}{*}{$\begin{array}{c}\text { Guideline } \\
\text { number }\end{array}$} & \multirow[b]{2}{*}{ Data requirements } & \multicolumn{8}{|c|}{ MRID exists } \\
\hline & & $\begin{array}{l}\text { Pyrethrins } \\
\text { (Pyblast) }\end{array}$ & Permethrin & Cyflutherin & Fipronil & Diflu-benzuron & Antimycin-A & Rotenone & $\begin{array}{c}\text { Emamectin } \\
\text { benzoate }\end{array}$ \\
\hline 835.1230 & $\begin{array}{l}\text { Adsorption/de-sorption } \\
\text { (batch-equilibrium) }\end{array}$ & N/A & Yes & Yes & Yes & 2 & Yes & N/A & Yes \\
\hline 835.2120 & Hydrolysis & Yes & Yes & Yes & Yes & Yes & Yes & N/A & Yes \\
\hline 835.2240 & Photodegradation in water & N/A & Yes & Yes & Yes & N/A & N/A & N/A & Yes \\
\hline 835.4300 & Aerobic aquatic & Yes & Yes & Yes & Yes & Yes & N/A & N/A & Yes \\
\hline 835.4400 & Anaerobic aquatic & Yes & Yes & Yes & Yes & Yes & N/A & N/A & Yes \\
\hline 835.6200 & Aquatic (sediment) & $\mathrm{N} / \mathrm{A}$ & N/A & Yes & 4 & N/A & $\mathrm{N} / \mathrm{A}$ & $\mathrm{N} / \mathrm{A}$ & N/A \\
\hline
\end{tabular}

835.6200

Aquatic (sediment) 
Table 2. The U.S. Environmental Protection Agency guideline number for section 850-ecological effects, type of data requirement. A “Yes" indicates there are data accepted by the U.S. Environmental Protection Agency.

[MRID, Master Record Identifier (indicates the most recent registration has been approved); N/A, no data available; a number indicates the quantity of journal articles that may provide support for approval of that guideline.]

\begin{tabular}{|c|c|c|c|c|c|c|c|c|c|}
\hline \multirow{2}{*}{$\begin{array}{l}\text { Guideline } \\
\text { number }\end{array}$} & \multirow[b]{2}{*}{ Data requirements } & \multicolumn{8}{|c|}{ MRID exists } \\
\hline & & $\begin{array}{l}\text { Pyrethrins } \\
\text { (Pyblast) }\end{array}$ & Permethrin & Cyflutherin & Fipronil & Diflu-benzuron & Antimycin-A & Rotenone & $\begin{array}{c}\text { Emamectin } \\
\text { benzoate }\end{array}$ \\
\hline 850.1010 & $\begin{array}{l}\text { Acute toxicity freshwater } \\
\text { invertebrates }\end{array}$ & Yes & Yes & Yes & Yes & Yes & Yes & Yes & Yes \\
\hline 850.1025 & $\begin{array}{l}\text { Acute toxicity estuarine } \\
\text { organisms }\end{array}$ & Yes & N/A & Yes & Yes & Yes & N/A & N/A & Yes \\
\hline 850.1035 & $\begin{array}{l}\text { Acute toxicity marine } \\
\text { organisms }\end{array}$ & Yes & N/A & $\mathrm{N} / \mathrm{A}$ & Yes & Yes & $\mathrm{N} / \mathrm{A}$ & N/A & Yes \\
\hline 850.1045 & Freshwater fish toxicity & Yes & N/A & Yes & Yes & Yes & Yes & Yes & Yes \\
\hline 850.1300 & $\begin{array}{l}\text { Aquatic invertebrate life } \\
\text { cycle (freshwater) }\end{array}$ & N/A & N/A & Yes & Yes & Yes & N/A & Yes & N/A \\
\hline 850.1400 & $\begin{array}{l}\text { Fish early-life stage } \\
\text { (freshwater) }\end{array}$ & N/A & Yes & Yes & Yes & Yes & N/A & Yes & Yes \\
\hline 850.2100 & Avian oral toxicity & Yes & Yes & Yes & Yes & Yes & N/A & Yes & Yes \\
\hline 850.2200 & Avian dietary toxicity & Yes & Yes & Yes & Yes & Yes & N/A & Yes & Yes \\
\hline 850.2300 & Avian reproduction & Yes & Yes & Yes & Yes & Yes & N/A & N/A & N/A \\
\hline 850.4100 & Seedling emergence & N/A & N/A & N/A & 1 & N/A & N/A & N/A & N/A \\
\hline 850.4150 & Vegetative vigor & N/A & N/A & N/A & N/A & N/A & N/A & N/A & N/A \\
\hline 850.4400 & $\begin{array}{l}\text { Aquatic plant growth } \\
\text { (algal and aquatic } \\
\text { vascular plant toxicity) }\end{array}$ & N/A & N/A & 1 & Yes & N/A & N/A & N/A & Yes \\
\hline
\end{tabular}


Table 3. The U.S. Environmental Protection Agency guideline number for Section 870-health effects, type of data requirement. A "Yes" indicates there are data accepted by the U.S. Environmental Protection Agency.

[MRID, Master Record Identifier (indicates the most recent registration has been approved); N/A, no data available; a number indicates the quantity of journal articles that may provide support for approval of that guideline.]

\begin{tabular}{|c|c|c|c|c|c|c|c|c|c|}
\hline \multirow{2}{*}{$\begin{array}{l}\text { Guideline } \\
\text { number }\end{array}$} & \multirow[b]{2}{*}{ Data requirements } & \multicolumn{8}{|c|}{ MRID exists } \\
\hline & & $\begin{array}{l}\text { Pyrethrins } \\
\text { (Pyblast) }\end{array}$ & Permethrin & Cyflutherin & Fipronil & Diflu-benzuron & Antimycin-A & Rotenone & $\begin{array}{c}\text { Emamectin } \\
\text { benzoate }\end{array}$ \\
\hline 870.1100 & Acute oral toxicity-rat & Yes & Yes & Yes & Yes & Yes & Yes & Yes & Yes \\
\hline 870.1200 & Acute dermal toxicity & Yes & Yes & Yes & Yes & Yes & Yes & Yes & N/A \\
\hline 870.1300 & $\begin{array}{l}\text { Acute inhalation toxicity- } \\
\text { rat }\end{array}$ & Yes & N/A & Yes & Yes & Yes & Yes & Yes & N/A \\
\hline 870.2400 & $\begin{array}{l}\text { Primary eye irritation- } \\
\text { rabbit }\end{array}$ & Yes & Yes & Yes & 10 & Yes & Yes & Yes & N/A \\
\hline 870.2500 & $\begin{array}{l}\text { Primary dermal irritation- } \\
\text { animal }\end{array}$ & Yes & Yes & Yes & Yes & Yes & Yes & Yes & N/A \\
\hline 870.2600 & $\begin{array}{l}\text { Dermal sensitization- } \\
\text { animal }\end{array}$ & Yes & Yes & Yes & Yes & Yes & Yes & Yes & N/A \\
\hline 870.6200 & Acute neurotoxicity-rat & Yes & Yes & Yes & Yes & N/A & N/A & 8 & Yes \\
\hline
\end{tabular}


Table 4. The U.S. Environmental Protection Agency guideline number for Section 875 -occupational and residential exposure, type of data requirement. A “Yes” indicates there are data accepted by the U.S. Environmental Protection Agency.

[MRID, Master Record Identifier (indicates the most recent registration has been approved); N/A, no data available; a number indicates the quantity of journal articles that may provide support for approval of that guideline.]

\begin{tabular}{|c|c|c|c|c|c|c|c|c|c|}
\hline \multirow[b]{2}{*}{$\begin{array}{l}\text { Guideline } \\
\text { number }\end{array}$} & \multirow[b]{2}{*}{ Data requirements } & \multicolumn{8}{|c|}{ MRID exists } \\
\hline & & $\begin{array}{c}\text { Pyrethrins } \\
\text { (Pyblast) }\end{array}$ & Permethrin & Cyflutherin & Fipronil & Diflu-benzuron & Antimycin-A & Rotenone & $\begin{array}{c}\text { Emamectin } \\
\text { benzoate }\end{array}$ \\
\hline 875.1100 & $\begin{array}{l}\text { HA dermal outdoor } \\
\text { exposure }\end{array}$ & Yes & Yes & N/A & N/A & N/A & N/A & N/A & $\mathrm{N} / \mathrm{A}$ \\
\hline 875.1200 & $\begin{array}{l}\text { HA dermal indoor } \\
\text { exposure }\end{array}$ & Yes & Yes & 4 & Yes & $\mathrm{N} / \mathrm{A}$ & $\mathrm{N} / \mathrm{A}$ & $\mathrm{N} / \mathrm{A}$ & N/A \\
\hline 875.1300 & $\begin{array}{l}\text { HA inhalation outdoor } \\
\text { exposure }\end{array}$ & Yes & Yes & Yes & Yes & $\mathrm{N} / \mathrm{A}$ & $\mathrm{N} / \mathrm{A}$ & N/A & $\mathrm{N} / \mathrm{A}$ \\
\hline 875.1400 & $\begin{array}{l}\text { HA inhalation indoor } \\
\text { exposure }\end{array}$ & Yes & Yes & Yes & $\mathrm{N} / \mathrm{A}$ & $\mathrm{N} / \mathrm{A}$ & $\mathrm{N} / \mathrm{A}$ & N/A & N/A \\
\hline 875.2100 & $\begin{array}{l}\text { PA human dislodgeable } \\
\text { foliar residue and turf } \\
\text { transferable residues }\end{array}$ & Yes & Yes & N/A & N/A & N/A & N/A & N/A & N/A \\
\hline 875.2200 & $\begin{array}{l}\text { PA human soil residue } \\
\text { dissipation }\end{array}$ & Yes & Yes & N/A & 2 & $\mathrm{~N} / \mathrm{A}$ & N/A & N/A & N/A \\
\hline 875.2300 & $\begin{array}{l}\text { PA human indoor } \\
\text { surface residue } \\
\text { dissipation }\end{array}$ & Yes & Yes & N/A & $\mathrm{N} / \mathrm{A}$ & $\mathrm{N} / \mathrm{A}$ & N/A & N/A & N/A \\
\hline 875.2400 & $\begin{array}{l}\text { PA human dermal } \\
\text { exposure }\end{array}$ & Yes & Yes & Yes & N/A & $\mathrm{N} / \mathrm{A}$ & $\mathrm{N} / \mathrm{A}$ & N/A & N/A \\
\hline 875.2500 & $\begin{array}{l}\text { PA human inhalation } \\
\text { exposure }\end{array}$ & Yes & Yes & Yes & N/A & N/A & N/A & $\mathrm{N} / \mathrm{A}$ & N/A \\
\hline
\end{tabular}


will suffer sublethal effects at concentrations required for crayfish control (Floyd and others, 2008; table 2.3). Primary metabolites of permethrin are less toxic to invertebrates and fish than permethrin (Canadian Council of Ministers of the Environment, 2006).

\section{Environmental Persistence}

Permethrin binds strongly to sediment, degrades rapidly in water (Peay, 2001), and degrades by photolysis (Canadian Council of Ministers of the Environment, 2006). Permethrin is metabolized faster than the type-2 pyrethroid cyfluthrin in some species (Fojut and others, 2012). Pyrethroids rapidly bind to organic matter, plants, and sediment (O'Reilly, 2015). Many synthetic pyrethroids have similar bioconcentration factors (table 2.9). Pyrethroids are rapidly metabolized and do not bioaccumulate or biomagnify (Haya and others, 2005; Ros and others, 2005).

\section{Registration Data Gaps for Permethrin}

Data gaps for permethrin are identified in tables 1-4. Permethrin is registered with EPA as a restricted-use terrestrial pesticide (Palmquist and others, 2012). Information from the literature search did not indicate that data existed to fill gaps identified in tables 1-4 for use as a crayfish pesticide. No relevant data were identified for: 835.6200-aquatic (sediment), 850.1025-oyster acute toxicity test (shell deposition), 850.1035-mysid acute toxicity test, 850.4100 -seedling emergence, 850.4150 -vegetative vigor, 850.4400 -aquatic plant growth, or 870.1300 -acute inhalation toxicity.

\section{Type-2 Pyrethroids (Primarily Cyfluthrin)}

Type-2 pyrethroids (cyhalothrin, cyfluthrin (Baythroid®), cypermethrin, deltamethrin, etc.) contain an $\alpha$-cyano group (Wolansky and others, 2006) and produce stimulus-dependent nerve depolarization and blockage in target organisms (Palmquist and others, 2012).

\section{Aquatic Toxicity}

Type-2 pyrethroids are more toxic to crayfish than type-1 pyrethroids (Table 2.5). Cyfluthrin and cypermethrin were used to eradicate crayfish in infested ponds treated at $25 \mu \mathrm{g} / \mathrm{L}$ and $20 \mu \mathrm{g} / \mathrm{L}$, respectively (Bills and Marking, 1988; Sandodden and Johnsen, 2010). Water temperature during treatment can substantially affect toxicity of type-2 pyrethroids (Table 2.6). Dissolved organic material—often present in field settings but not in laboratory water-binds to cyfluthrin, alters the biologically available levels, reduces the uptake, and reduces its toxicological effect (Fojut and others, 2010; Fojut and others, 2012).

Most fishes are less susceptible to cyfluthrin than crayfish, but other aquatic invertebrates are at risk at the required cyfluthrin treatment concentrations (table 2.7). Pyrethroids have low toxicity to mammals and birds (Palmquist and others, 2012). Piperonyl butoxide, a commonly used synergistic additive, is known to increase the toxicity of pyrethroids (Weston and others, 2006; Fojut and others, 2010). As an example, the 48 -hour $\mathrm{LC}_{50}$ for Daphnia magna exposed to cyfluthrin decreased from $0.62 \mu \mathrm{g} / \mathrm{L}$ to $0.46 \mu \mathrm{g} / \mathrm{L}$ when piperonyl butoxide was added to cyfluthrin (Brausch and Smith, 2009).

\section{Environmental Persistence}

Type-2 pyrethroids have shorter half-lives (hours to days for deltamethrin) than type-1 pyrethroids (O'Reilly, 2015). The synthetic pyrethroids have low water solubility and have high organic carbon-water partition coefficients. Concentrations needed to eradicate crayfish should be assessed on site before treatment to account for differences in water chemistry. Alkaline conditions aid in the breakdown of pyrethroids (table 2.8), and pyrethroids rapidly bind to organic matter, plants, and sediment (O'Reilly, 2015). Bioconcentration factors are similar for different pyrethroids (table 2.9). Pyrethroids are rapidly metabolized and do not bioaccumulate or biomagnify (Haya and others, 2005; Ros and others, 2005).

\section{Registration Data Gaps for Cyfluthrin}

Data gaps for cyfluthrin are identified in tables 1-4.

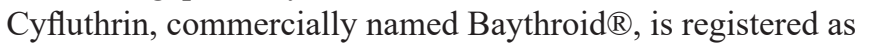
a restricted-use pesticide for terrestrial use by EPA. Literature exists that will likely support many of the guidelines required for aquatic use, particularly for guidelines required that are common between terrestrial and aquatic pesticides. Potential data have been reported for guidelines 850.4400 -aquatic plant growth (table 2.10; Ma 2005), 875.1200-human applicator dermal indoor exposure, 875.1400-human applicator inhalation indoor exposure and 875.230-post-application human indoor surface residue dissipation (Williams and others, 2003; Berger-Preiß and others, 2009; Keenan and others, 2010). No relevant data were identified for: 850.4400 -aquatic plant growth (algal and aquatic vascular plant toxicity), 875.2100 post-application human dislodgeable foliar residue and turf transferable residues, or 875.2200-post-application human soil residue dissipation. 


\section{Fipronil}

Fipronil, a phenylpyrazole, blocks inhibition sites on the nervous system, leading to the overexcitation of the nervous system (Simon-Delso and others, 2015).

\section{Aquatic Toxicity}

Fipronil and its breakdown products are toxic to crayfish (Table 2.11). Fipronil is commonly produced as a racemic mixture of the two enantiomers which vary in their toxicity (Konwick and others, 2005; Overmyer and others, 2007).

Fipronil is toxic to crayfish and other aquatic invertebrates (Table 2.12). Additionally, fipronil's breakdown products are toxic to aquatic invertebrates (Hainzl and Casida, 1996; Walse and others, 2004). Fipronil sulfone is 6.6 times more toxic and fipronil sulfide is 1.9 times more toxic to aquatic invertebrates than fipronil (Connelly, 2001). Concentrations required to eradicate crayfish will affect nontarget fish species (Table 2.12). Fipronil has moderate acute oral toxicity in rats and moderate acute dermal toxicity in rabbits (Keigwin, 2011).

Fipronil may have other toxicological effects. It has been reported that fipronil decreased copepod reproductive rates (Chandler and others, 2004). Fipronil increased thyroid follicular cell tumors in rats, which is why it is classified as a group C potential carcinogen (Keigwin, 2011).

\section{Environmental Persistence}

The persistence of fipronil can vary between terrestrial and aquatic environments. The half-life of fipronil on land is 128-300 days (Andrews and others, 2007), while in water is reported between 5.4 to 28 days (Andrews and others, 2007; Jinguji and others, 2013; Kasai and others, 2016). In a lab study, fipronil sediment concentration dropped 40 percent during a 28-day period (Dang and others, 2016). The breakdown products of fipronil, desulfinyl fipronil, fipronil sulfide, and fipronil sulphone (Schlenk and others, 2001) have halflives of 217-497, 195-352, and 502-589 days in sediment, respectively (Lin and others, 2009). Desulfinyl fipronil is more stable than fipronil (Connelly, 2001). Fipronil sulfone has higher bioaccumulation potential than fipronil (Konwick and others, 2006). Summarized data on fipronil degradation and physical chemical properties is in Table 2.13.

\section{Registration Data Gaps for Fipronil}

Data gaps for fipronil are identified in Tables 1-4. Fipronil is registered with EPA as a terrestrial insecticide and has a variety of uses in the United States including in agriculture, as a flea and tick control agent, and for household use (Schlenk and others, 2001; Biever and others, 2003; Key and others, 2003). Due to these common uses, many of the guidelines already have published data. Potential data have been reported for guidelines 835.6200-aquatic (sediment; Qu and others, 2016; Wang and others, 2019) and guideline 850.4100 -terrestrial plant toxicity of fipronil (Dan and others, 2012). No relevant data were identified for guidelines: 850.4150 -vegetative vigor, 870.2400 -acute eye irritation, or human exposure (Subpart K).

\section{Antimycin-A}

Antimycin-A, a group of molecules created as a byproduct of Streptomyces spp. metabolism, is an inhibitor of oxidative phosphorylation, resulting in the breakdown of cellular respiration and ATP synthesis (Kim and others, 1999).

\section{Aquatic Toxicity}

The toxicity of antimycin-A varies among crayfish species, and crayfish are generally less sensitive to antimycin-A than fish (table 2.16; Lesser, 1970; Perlman, 1973).

Antimycin-A was approved by EPA to control invasive fishes and was commonly used to "reset," (remove all species for native fish restocking) in high mountain streams. The use of antimycin-A to control invasive crayfish will result in the death of most fish species within the pond or stream (table 2.17).

\section{Environmental Persistence}

Antimycin-A does not bioaccumulate in organisms (Greselin and Herr, 1974), likely because it rapidly decomposes. The half-life for antimycin-A is 11-hours at $\mathrm{pH} \mathrm{6,7.1} \mathrm{hours} \mathrm{at} \mathrm{pH}$ 7, and 3.4-hours at pH 9 (Turner and others, 2007).

\section{Registration Data Gaps for Antimycin-A}

Data gaps for antimycin-A are identified in tables 1-4. Even though antimycin-A was registered as an aquatic pesticide by EPA, data gaps still exist. No relevant data were identified for guidelines: 835.2240-photodegradation in water, 835.4300-aerobic aquatic, 835.4400-anaerobic aquatic, 835.6200-aquatic (sediment), 850.1023-acute toxicity estuarine organisms, 850.1035 -acute toxicity marine organisms, 850.1300-aquatic invertebrate life cycle (freshwater), 850.1400-fish early-life stage (freshwater), 850.2100-avian oral toxicity, 850.2200 -avian dietary toxicity, 850.2300 -avian reproduction, 850.4100-seedling emergence, 850.4150 vegetative vigor, 850.4400 -aquatic plant growth (algal and aquatic vascular plant toxicity), or 870.6200-aerobic aquatic. Additionally, no relevant publications were identified for Subpart K-human exposure. 


\section{Rotenone}

Rotenone, a botanical extracted from the roots of tropical plants, is an inhibitor of oxidative phosphorylation, resulting in the breakdown of cellular respiration and ATP synthesis (Gupta, 2014).

\section{Aquatic Toxicity}

It has been reported that rotenone toxicity differed among crayfish species. Orconectes immunis (calico crayfish) survived rotenone concentrations as much as 0.5 milligrams per liter (mg/L) when exposed for 72-hours (Ling, 2003) whereas rotenone was not toxic to Procambarus zonangulus (White River crayfish) at concentrations up to $3 \mathrm{mg} / \mathrm{L}$ (Wujtewicz and others, 1997). Bills and Marking (1988) reported 10 $\mathrm{mg} / \mathrm{L}$ required 72 -hours to kill rusty crayfish. Rotenone 96-hour $\mathrm{LC}_{50}$ values of 6.2 and $7.5 \mathrm{mg} / \mathrm{L}$ were determined for Macrobrachium rosenbergii (giant freshwater prawn) (Ogunsanya and others, 2011).

Rotenone is more toxic to many fish species than it is to crayfish. Rotenone's application rate for fish removal is 0.025 to $0.2 \mathrm{mg} / \mathrm{L}$ as active ingredient (EPA, 2019). It has been reported to be toxic to Morone americana (white perch) at $0.15 \mathrm{mg} / \mathrm{L}$ (Wujtewiczand others, 1997). Rotenone produces 24-hour $\mathrm{LC}_{50}$ values between 5 and $100 \mu \mathrm{g} / \mathrm{L}$ in fish species (Ling, 2003). The 72-hour $\mathrm{LC}_{50}$ value for Cyclops sp. isave less than $100 \mu \mathrm{g} / \mathrm{L}$ (Stebbing and others, 2014). A 48-hour $\mathrm{LC}_{50}$ of $0.219 \mathrm{mg} / \mathrm{L}$ was reported for Dreissena polymorpha (zebra mussels) (Stebbing and others, 2014).

\section{Environmental Persistence}

Rotenone breaks down quickly in the presence of heat, light, or oxygen. Rotenone has an aquatic half-life of less than one day at $24^{\circ} \mathrm{C}$ but 3.5 days at temperatures of $0^{\circ} \mathrm{C}$ (Gilderhus and others, 1986). The fish tissue half-life of rotenone is about 1 day and there is a low potential to accumulate (Robertson and Smith-Vaniz, 2008).

\section{Registration Data Gaps for Rotenone}

Data gaps for rotenone are identified in tables 1-4. Rotenone is registered by EPA as a restricted-use pesticide due to aquatic, acute oral, and inhalation toxicity. Rotenone is a broad-spectrum pesticide and is not selective to crayfish. Rotenone is used by aquatic resource managers to "reset" some aquatic systems. Because rotenone is already registered for use to control fishes, data to expand its label to include crayfish control would be minimal. Data gaps exist for the following guidelines: all of Section 835-fate, transport and transformation, 850.1025-acute toxicity estuarine organisms, 850.1035-acute toxicity marine organisms, 850.2300-avian reproduction, 850.4100-seedling emergence, 850.4150-vegetative vigor, 850.4400-aquatic plant growth (algal and aquatic vascular plant toxicity), and all of Subpart K-human exposure.

One area of concern is related to guideline 870.6222-acute neurotoxicity rat. Several publications suggest a link between rotenone exposure and Parkinson-like symptoms in humans. The first link between a Parkinson-like neurotoxicity and exposure to rotenone was published in 1997 (Ferrante and others, 1997), and the relation between oxidative stress and exposure is part of this neurodegeneration (Saravanan and others, 2005). The introduction of a mouse neurodegeneration model to the literature was published in 2007 (Inden and others, 2007). More publications on the mouse model exist (Madathil and others, 2013; Ojha and others, 2015; Wu and others, 2015; Nie and others, 2019; and Johnson and others, 2019).

\section{Physiological Modifiers}

\section{Diflubenzuron}

Diflubenzuron, a benzoylurea, interferes with chitin production and triggers premature molting (Cunningham, 1986).

\section{Aquatic Toxicity}

Little data for crayfish toxicity was identified; however, diflubenzuron is extremely toxic to other invertebrates such as shrimp and crabs (Hyatt, 2004). Diflubenzuron was reported to cause behavioral, growth, survival, and reproductive changes in crustaceans at concentrations as low as $0.062-2 \mu \mathrm{g} / \mathrm{L}$ (Eisler, 1992), but no change in red swamp crayfish population size was observed when exposed to these concentrations (Cunningham, 1986). Acute crayfish toxicity data is not available. Toxicity of diflubenzuron to crustaceans is documented in table 2.14.

The U.S. Fish and Wildlife Service reported algae, amphibians, fish, and mollusks are tolerant of diflubenzuron and observed no adverse effects when these organisms were exposed to concentrations as high as $45 \mu \mathrm{g} / \mathrm{L}$ (Eisler, 1992). Diflubenzuron is used at concentrations between 2.5 and $16 \mu \mathrm{g} / \mathrm{L}$ to eradicate dipterans (Eisler, 1992). Populations of cladocerans, copepods, corixids, and springtails were suppressed when exposed to these concentrations but recovered within 80 days (Eisler, 1992).

\section{Registration Data Gaps for Diflubenzuron}

Data gaps for diflubenzuron are identified in tables 1-4. Diflubenzuron is registered with EPA as a terrestrial insecticide. Potential data have been reported for guidelines 835.1230-adsorption/desorption (table 2.15; Sundaram and others, 1997), 835.2240-photodegradation in water (Mabury and Crosby, 1996), 835.6200-aquatic (sediment; Mabury and 
Crosby, 1996), and 875.1100-human applicator dermal exposure (Roitzsch and others 2019). The data gaps for registration includes: 870.6200-acute neurotoxicity, 158.660-nontarget plant protection data, and human exposure (Subpart K), except 875.240-post-application human dermal exposure and 875.2200-post-application human soil residue dissipation, as identified in tables $1-4$.

\section{Emamectin Benzoate}

Emamectin benzoate, a second generation avermectin insecticide, prevents electrical impulse transmission in muscle and nerve tissues of invertebrates (El-Saber Batiha and others, 2020).

\section{Aquatic Toxicity}

Emamectin benzoate inhibits muscular contraction (Fanigliulo and Sacchetti, 2008). Female Homarus americanus (American lobsters) exposed to emamectin benzoate at concentrations 0.22 and 0.39 microgram per gram lost their eggs (Waddy and others, 2007). Premature molting occurred in 89 percent of lobsters dosed at 0.125 microgram per gram (Waddy and others, 2010).

Emamectin benzoate is more toxic to aquatic invertebrates than fishes (Shanaman and Carey, 2008). Reported $\mathrm{LC}_{50} \mathrm{~s}$ for aquatic invertebrates ranged from 0.04 to $490 \mu \mathrm{g} / \mathrm{L}$, while $\mathrm{LC}_{50} \mathrm{~s}$ for fish ranged from 174 to $1,430 \mu \mathrm{g} / \mathrm{L}$. Mysidopsis bahia (mysid shrimp) are more sensitive than daphnids to chronic exposure (Shanaman and Carey, 2008).

\section{Environmental Persistence}

Data for emamectin benzoate environmental fate can be read in table 2.18. Emamectin benzoate binds quickly to soil and has a short soil half-life. Emamectin benzoate has bioconcentration factors of 69 and 98 in whole fish and visceral tissue, respectively (Shanaman and Carey, 2008).

\section{Registration Data Gaps for Emamectin Benzoate}

Data gaps for emamectin benzoate are identified in tables 1-4. Emamectin benzoate registered by EPA for use as injection and sprayed application on trees to control arthropod pests (Anderson and others, 2009). Potential data have been reported for guidelines 950.2300-avian reproduction (O'Grodnick and others, 1998) and 87.6200-acute neurotoxicity in rats (Wise and others, 1997). Data gaps exist in the following guidelines: 835.6200-aquatic (sediment), 850.1100 -aquatic invertebrate acute toxicity test, freshwater daphnids, 850.1300-aquatic invertebrate life cycle (freshwater), 850.4100-seedling emergence, 850.4150 -vegetative vigor, 870.1200 -acute dermal toxicity, 870.1300 -acute inhalation toxicity rat, 870.2400-primary eye irritation rabbit, 870.2500-primary dermal irritation animal, 870.2600-acute neurotoxicity rat, and all of Subpart K-human exposure.

\section{Summary Considerations}

The use of pesticides is an important component of an integrated pest management strategy for controlling nonnative crayfish (Bills and Marking, 1988; Hyatt, 2004; Rotherham, 2009; O'Reilly, 2015). Crayfish-specific pesticides are greatly desired so that effects on native fauna are minimized and degradation of the ecosystem is decreased while populations of nonnative crayfish are controlled. The use of multiple pesticides acting on different physiological processes could be used to increase selectivity of the treatment while also decreasing the amounts of pesticides needed to kill crayfish. Life stage is a critical consideration for some pesticides. Molting crayfish are more susceptible to pesticides, and several pesticides are most effective against younger crayfish. In addition, physiological modifiers could potentially force crayfish to prematurely molt. This would significantly lower the required dose to kill crayfish. Emamectin benzoate stimulated premature molting and molted crayfish have shown increased sensitivity to other pesticides (Brown and Avault, 1975; Waddy and others, 2010). Similarly, piperonyl butoxide is commonly used as an additive to increase the toxicity of synthetic pyrethroids. Piperonyl butoxide would also require EPA registration before use in aquatic environments for use as a crayfish pesticide.

Some of the species listed in the review are primary and tertiary burrowers. The act of burrowing by crayfish may limit the crayfish's exposure, interfering with successful chemical treatment. If a pesticide is present in the pond, crayfish are more likely to be exposed to a lethal concentration outside of their burrows. The effects of changes in burrow water chemistry must be considered when trying to control crayfish as some pesticides do not kill crayfish in their burrows. For example, the presence of organic matter decreases bioavailability and efficacy of pyrethroids; carboxylic acid content in organic matter changes the partition coefficient of pyrethroids, altering pyrethroid bioavailability and toxicity (Yang and others, 2007).

Based on this review, pyrethroids have the greatest promise as a crayfish pesticide. Specifically, the synthetic type-2 pyrethroid, cyfluthrin (Baythroid $\AA$ ), seems to be the best candidate for development of a crayfish pesticide. Cyfluthrin has several positive properties desired as a crayfish pesticide, including some potency to crayfish, a margin of safety for some nontarget organisms, and a short aquatic persistence. Cyfluthrin is toxic to other aquatic invertebrates at concentrations needed for crayfish eradication, but it also offers rapid ecosystem recovery compared to other pyrethroids and other candidate chemicals listed in this document in general. 


\section{Acknowledgments}

We would like to acknowledge Lisa L. Hein (Upper Midwest Environmental Sciences Center [UMESC] Technical Information Specialist) for completing the primary literature search for this literature review. Additionally, we acknowledge Terrance D. Hubert (UMESC Supervisory Chemist), Stephen R. Lantz (UMESC Supervisory Chemist), and Jon J. Amberg (UMESC Supervisory Biologist) for assisting with this literature review.

\section{References Cited}

Alderman, D.J., 1996, Geographical spread of bacterial and fungal diseases of crustaceans: Revue Scientifique et Technique (International Office of Epizootics), v. 15, no. 2, p. 603-632.

Anderson, B., Doelling, P., and Hetrick, J.A., 2009, Section 3 request for a new use of the insecticide emamectin benzoate (PC Code 122806): United States Environmental Protection Agency, Washington, D.C., p. 3-31.

Andrews, N., Odenkirchen, E., and Hetrick, J., 2007, Fipronil-environmental fate and ecological effects assessment and characterization for section 18 registration of in-furrow applications to rutabaga and turnips: United States Environmental Protection Agency, Washington, D.C., p. 4-72.

Antonious, G.F., Patel, G.A., Snyder, J.C., and Coyne, M.S., 2011, Pyrethrins and piperonyl butoxide adsorption to soil organic matter: Journal of Environmental Science and Health. Part. B, Pesticides, Food Contaminants, and Agricultural Wastes, v. 39, no. 1, p. 19-32.

Aquiloni, L., Martin, M.P., Gherardi, F., and DiéguezUribeondo, J., 2011, The North American crayfish Procambarus clarkii is the carrier of the oomycete Aphanomyces astaci in Italy: Biological Invasions, v. 13, no. 2, p. 359-367.

Bergerhouse, D.L., 1992, Lethal effects of elevated pH and ammonia on early life stages of walleye: North American Journal of Fisheries Management, v. 12, no. 2, p. 356-366.

Berger-Preiß, E., Koch, W., Gerling, S., Kock, H., and Appel, K.E., 2009, Use of biocidal products (insect sprays and electro-vaporizer) in indoor areas-Exposure scenarios and exposure modeling: International Journal of Hygiene and Environmental Health, v. 212, no. 5, p. 505-518.

Bierbower, S.M., and Cooper, R.L., 2010, The effects of acute carbon dioxide on behavior and physiology in Procambarus clarkii: Journal of Experimental Zoology. Part A, Ecological Genetics and Physiology, v. 313A, no. 8, p. 484-497.
Biever, R.C., Hoberg, J.R., Jacobson, B., Dionne, E., Sulaiman, M., and McCahon, P., 2003, Icon ${ }^{\circledR}$ rice seed treatment toxicity to crayfish (Procambarus clarkii) in experimental rice paddies: Environmental Toxicology and Chemistry: An International Journal, v. 22, no. 1, p. $167-174$.

Bills, T.D., and Marking, L.L., 1988, Control of nuisance populations of crayfish with traps and toxicants: Progressive Fish-Culturist, v. 50, no. 2, p. 103-106.

Brausch, J.M., and Smith, P.N., 2009, Development of resistance to cyfluthrin and naphthalene among Daphnia magna: Ecotoxicology (London, England), v. 18, no. 5, p. 600-609.

Canadian Council of Ministers of the Environment, 2006, Canadian water quality guidelines for the protection of aquatic life: Permethrin: Canadian environmental quality guidelines: Canadian Council of Ministers of the Environment. Winnepeg, p. 7.

Cecchinelli, E., Aquiloni, L., Maltagliati, G., Orioli, G., Tricarico, E., and Gherardi, F., 2012, Use of natural pyrethrum to control the red swamp crayfish Procambarus clarkii in a rural district of Italy —Pest Management Science, formerly: Pesticide Science, v. 68, no. 6, p. $839-844$.

Chambers, P.A., Hanson, J.M., Burke, J.M., and Prepas, E.E., 1990, The impact of the crayfish Orconectes virilis on aquatic macrophytes: Freshwater Biology, v. 24, no. 1, p. $81-91$.

Chandler, G.T., Cary, T.L., Bejarano, A.C., Pender, J., and Ferry, J.L., 2004, Population consequences of fipronil and degradates to copepods at field concentrations-An integration of life cycle testing with Leslie matrix population modeling: Environmental Science \& Technology, v. 38, no. 23 , p. 6407-6414.

Connelly, P., 2001, Environmental fate of fipronil. California Environmental Protection Agency Department of Pesticide Regulation, p. 1-17.

Cunningham, P.A., 1986, A review of toxicity testing and degradation studies used to predict the effects of diflubenzuron (Dimilin ${ }^{\circledR}$ ) on estuarine crustaceans: Environmental Pollution. Series A. Ecological and Biological, v. 40, no. 1, p. 63-86.

Cupp, A.R., Smerud, J.R., Thomas, L.M., Waller, D.L., Smith, D.L., and Erickson, R.A., ad Gaikowski, M.P., 2020, Toxicity of carbon dioxide to freshwater fishesImplications for aquatic invasive species management: Environmental Toxicology, v. 39, no. 11, p. 2247-2255. 
Dan, L.D.M., Dan, H.D.A., Piccinin, G.G., Ricci, T.T., and Ortiz, A.H.T., 2012, Insecticide treatment and physiological quality of soybean seeds: Revista Caatinga, v. 25, no. 1, p. $45-51$.

Dang, V.D., Kroll, K.J., Supowit, S.D., Halden, R.U., and Denslow, N.D., 2016, Bioaccumulation of legacy and emerging organochlorine contaminants in Lumbriculus variegatus: Archives of Environmental Contamination and Toxicology, v. 71, no. 1, p. 60-69.

Donaldson. M.R., Amberg, J., Adhikari, S., Cupp, A., Jenson, N., Romine, J., Wright, A., Gaikowski, M., and Suski, C.D., 2016, Carbon dioxide as a tool to deter the movement of invasive bigheaded carps: American Fisheries Society, v. 145 , no. 3 , p. 657-670.

Dorn, N.J., and Mittelbach, G.G., 2004, Effects of a native crayfish (Orconectes virilis) on the reproductive success and nesting behavior of sunfish (Lepomis spp.): Canadian Journal of Fisheries and Aquatic Sciences, v. 61, no. 11, p. 2135-2143.

Eisler, R., 1992, Diflubenzuron hazards to fish, wildlife, and invertebrates: a synoptic review: U.S. Fish and Wildlife Service Biological Report, p. 1-48.

Eisler, R., 1985, Mirex hazards to fish, wildlife, and invertebrates: a synoptic review: U.S. Fish and Wildlife Service Biological Report, p. 1-80.

El-Saber Batiha, G., Alqahtani, A., Ilesanmi, O.B., Saati, A.A., El-Mleeh, A., Hetta, H.F., and Beshbishy, A.M., 2020, Avermectin Derivatives, Pharmacokinetics, Therapeutic and Toxic Dosages, Mechanism of Action, and Their Biological Effects: Pharmaceuticals (Basel, Switzerland), v. 13, no. 8, p. 196.

Fanigliulo, A., and Sacchetti, M., 2008, Emamectin benzoate - New insecticide against Helicoverpa armigera: Communications in Agricultural and Applied Biological Sciences, v. 73, no. 3, p. 651-653.

Ferrante, R.J., Schulz, J.B., Kowall, N.W., and Beal, M.F., 1997, Systemic administration of rotenone produces selective damage in the striatum and globus pallidus, but not in the substantia nigra: Brain Research, v. 753, no. 1, p. 157-162.

Fischer, S.A., and Hall, L.W., 1992, Environmental concentrations and aquatic toxicity data on diflubenzuron (Dimilin): Critical Reviews in Toxicology, v. 22, no. 1, p. 45-79.

Floyd, E.Y., Geist, J.P., and Werner, I., 2008, Acute, sublethal exposure to a pyrethroid insecticide alters behavior, growth, and predation risk in larvae of the fathead minnow (Pimephales promelas): Environmental Toxicology and Chemistry: An International Journal, v. 27, no. 8, p. $1780-1787$.
Fojut, T.L., Chang, S., and Tjeerdema, R.S., 2010, Water quality criteria report for cyfluthrin. Phase III-Application of the pesticide water quality criteria methodology. Central Valley Regional Water Quality Control Board, p. 1-40.

Fojut, T.L., Palumbo, A.J., and Tjeerdema, R.S., 2012, Aquatic life water quality criteria derived via the UC Davis method-II. Pyrethroid insecticides: Reviews of Environmental Contamination and Toxicology, v. 216, p. 51-103.

Fredricks, K.T., Tix, J.A., Smerud, J.R., and Cupp, A.R., 2020, Laboratory trials to evaluate carbon dioxide as a potential behavioral control method for invasive red swamp (Procambarus clarkii) and rusty crayfish (Faxonius rusticus): Management of Biological Invasions, v. 11, no. 2, p. 259-278.

Freeman, M.A., Turnbull, J.F., Yeomans, W.E., and Bean, C.W., 2010, Prospects for management strategies of invasive crayfish populations with an emphasis on biological control: Aquatic Conservation, v. 20, no. 2, p. 211-223.

Gamradt, S.C., Kats, L.B., and Anzalone, C.B., 1997, Aggression by non-native crayfish deters breeding in California newts: Conservation Biology, v. 11, no. 3, p. 793-796.

Gerberding, J., 2003, Toxicological profile for pyrethrin and pyrethroids. U.S. Department of Health and Human Services, p. 1-226.

Gherardi, F., Aquiloni, L., Diéguez-Uribeondo, J., and Tricarico, E., 2011, Managing invasive crayfish-Is there a hope?: Aquatic Sciences, v. 73, no. 2, p. 185-200.

Gilderhus, P.A., Allen, J.L., and Dawson, V.K., 1986, Persistence of rotenone in ponds at different temperatures: North American Journal of Fisheries Management, v. 6, no. 1, p. 129-130.

Gladman, Z., Adams, C., Bean, C., Sinclair, C., and Yeomans, W., 2009, Signal crayfish in Scotland: in Crayfish Conservation in the British Isles, Leeds, United Kingdom, 2009, Proceedings: Leeds, United Kingdom, Crayfish Conservation in the British Isles, p. 43-48.

Greselin, E., and Herr, F., 1974, Further toxicity studies with antimycin, a fish eradicant: Journal of Agricultural and Food Chemistry, v. 22, no. 6, p. 996-998.

Griffiths, S.W., Collen, P., and Armstrong, J.D., 2004, Competition for shelter among over-wintering signal crayfish and juvenile Atlantic salmon: Journal of Fish Biology, v. 65 , no. 2 , p. $436-447$.

Gupta, R.C., 2014, Rotenone, in Wexler, P., ed., Encyclopedia of Toxicology 3rd ed.: Cambridge, Massachusetts, Academic Press, p. 185-187. 
Hainzl, D., and Casida, J.E., 1996, Fipronil insecticide-Novel photochemical desulfinylation with retention of neurotoxicity: Proceedings of the National Academy of Sciences of the United States of America, v. 93, no. 23, p. 12764-12767.

Hall, J., O’Brien, D., O’Brien, C., Baum, D., and Ballantyne, L., 2013, Impact of a natural pyrethrin biocide on two amphibians, common toad Bufo bufo and palmate newt Lissotriton helveticus, in Highland, UK: Conservation Evidence, v. 10, p. 70-72.

Hanson, J.M., Chambers, P.A., and Prepas, E.E., 1990, Selective foraging by the crayfish Orconectes virilis and its impact on macroinvertebrates: Freshwater Biology, v. 24, no. 1, p. 69-80.

Haya, K., Burridge, L.E., Davies, I.M., and Ervik, A., 2005, A review and assessment of environmental risk of chemicals used for the treatment of sea lice infestations of cultured salmon: Environmental Effects of Marine Finfish Aquaculture, p. 305-340.

Hein, C.L., Vander Zanden, M.J., and Magnuson, J.J., 2007, Intensive trapping and increased fish predation cause massive population decline of an invasive crayfish: Freshwater Biology, v. 52, no. 6, p. 1134-1146.

Hill, A.M., and Lodge, D.M., 1999, Replacement of resident crayfishes by an exotic crayfish-The roles of competition and predation: Ecological Applications, v. 9, no. 2, p. 678-690.

Holdich, D.M., and Gherardi, F., 1999, Crayfish in Europe as Alien Species-How to Make the Best of a Bad Situation?: Rotterdam, Netherlands, AA Balkema, p. 1-310.

Hyatt, M.W., 2004, Investigation of crayfish control technology: Arizona Game and Fish Department Cooperative Agreement 1448-20181, p. 1-72.

Imhoff, E.M., Mortimer, R.J., Christmas, M., and Dunn, A.M., 2012, Horizontal transmission of Thelohania contejeani in the endangered white-clawed (Austropotamobius pallipes) and the invasive signal crayfish (Pacifastacus leniusculus): Parasitology, v. 139, no. 11, p. 1471-1477.

Inden, M., Kitamura, Y., Takeuchi, H., Yanagida, T., Takata, K., Kobayashi, Y., Taniguchi, T., Yoshimoto, K., Kaneko, M., Okuma, Y., Taira, T., Ariga, H., and Shimohama, S., 2007, Neurodegeneration of mouse nigrostriatal dopaminergic system induced by repeated oral administration of rotenone is prevented by 4-phenylbutyrate, a chemical chaperone: Journal of Neurochemistry, v. 101, no. 6, p. 1491-1504.
James, J., Slater, F.M., Vaughan, I.P., Young, K.A., and Cable, J., 2015, Comparing the ecological impacts of native and invasive crayfish - Could native species' translocation do more harm than good?: Oecologia, v. 178, no. 1, p. 309-316.

Johnson, M.E., Zhou, X.F., and Bobrovskaya, L., 2019, The effects of rotenone on TH, BDNF and BDNF-related proteins in the brain and periphery-Relevance to early Parkinson's disease: Journal of Chemical Neuroanatomy, v. 97 , p. 23-32.

Jinguji, H., Thuyet, D.Q., Uéda, T., and Watanabe, H., 2013, Effect of imidacloprid and fipronil pesticide application on Sympetrum infuscatum (Libellulidae-Odonata) larvae and adults: Paddy and Water Environment, v. 11, no. 1-4, p. 277-284.

Kasai, A., Hayashi, T.I., Ohnishi, H., Suzuki, K., Hayasaka, D., and Goka, K., 2016, Fipronil application on rice paddy fields reduces densities of common skimmer and scarlet skimmer: Scientific Reports, v. 6, no. 1, p. 23055.

Keenan, J.J., Ross, J.H., Sell, V., Vega, H.M., and Krieger, R.I., 2010, Deposition and spatial distribution of insecticides following fogger, perimeter sprays, spot sprays, and crackand-crevice applications for treatment and control of indoor pests: Regulatory Toxicology and Pharmacology, v. 58, no. 2, p. 189-195.

Keigwin, R., Jr., 2011, Fipronil Summary Document Registration Review: EPA Docket number EPA-HQOPP-2011-0448, p. 1-21.

Kerby, J.L., Riley, S.P., Kats, L.B., and Wilson, P., 2005, Barriers and flow as limiting factors in the spread of an invasive crayfish (Procambarus clarkii) in southern California streams: Biological Conservation, v. 126, no. 3, p. $402-409$.

Key, P.B., Chung, K.W., Opatkiewicz, A.D., Wirth, E.F., and Fulton, M.H., 2003, Toxicity of the insecticides fipronil and endosulfan to selected life stages of the grass shrimp (Palaemonetes pugio): Bulletin of Environmental Contamination and Toxicology, v. 70, no. 3, p. 0533-0540.

Kim, H., Esser, L., Hossain, M.B., Xia, D., Yu, C., Rizo, J., van der Helm, D., and Deisenhofer, J., 1999, Structure of Antimycin A1, a Specific Electron Transfer Inhibitor of Ubiquinol-Cytochrome c Oxidoreductase: Journal of the American Chemical Society, v. 121, no. 20, p. 4902-4903.

Konwick, B.J., Fisk, A.T., Garrison, A.W., Avants, J.K., and Black, M.C., 2005, Acute enantioselective toxicity of fipronil and its desulfinyl photoproduct to Ceriodaphnia dubia: Environmental Toxicology and Chemistry: An International Journal, v. 24, no. 9, p. 2350-2355. 
Konwick, B.J., Garrison, A.W., Black, M.C., Avants, J.K., and Fisk, A.T., 2006, Bioaccumulation, biotransformation, and metabolite formation of fipronil and chiral legacy pesticides in rainbow trout: Environmental Science \& Technology, v. 40, no. 9, p. 2930-2936.

Lesser, B., 1970, Acute toxicities of antimycin A and juglone to selected aquatic organisms: La Crosse, Wisconsin, University of Wisconsin-La Crosse, master's thesis, 48 p.

Lin, K., Haver, D., Oki, L., and Gan, J., 2009, Persistence and sorption of fipronil degradates in urban stream sediments: Environmental Toxicology and Chemistry: An International Journal, v. 28, no. 7, p. 1462-1468.

Ling, N., 2003, Rotenone a review of its toxicity and use for fisheries management: Wellington, New Zealand, Department of Conservation, p. 1-36.

Longshaw, M., and Stebbing, P., eds., 2016, Biology and ecology of crayfish: Boca Raton, Florida, CRC Press, p. 287-323.

Mabury, S.A., and Crosby, D.G., 1996, Fate and disposition of diflubenzuron in rice fields: Environmental Toxicology and Chemistry: An International Journal, v. 15, no. 11, p. 1908-1913.

Madathil, S.K., Karuppagounder, S.S., and Mohanakumar, K.P., 2013, Sodium salicylate protects against rotenoneinduced Parkinsonism in rats: Synapse (New York, N.Y.), v. 67 , no. 8 , p. $502-514$.

Martín-Torrijos, L., Kokko, H., Makkonen, J., Jussila, J., and Dieguez-Uribeondo, J., 2019, Mapping 15 years of crayfish plague in the Iberian Peninsula-The impact of two invasive species on the endangered native crayfish: PLoS One, v. 14 , no. 8, p. e0219223.

Matsuda, K., 2011, Pyrethrin biosynthesis and its regulation in Chrysanthemum cinerariaefolium: Pyrethroids, v. 314, p. $73-81$.

Matsuzaki, S.S., Usio, N., Takamura, N., and Washitani, I., 2009, Contrasting impacts of non-native engineers on freshwater ecosystems - An experiment and meta-analysis: Oecologia, v. 158, no. 4, p. 673-686.

McCarthy, J.M., Hein, C.L., Olden, J.D., and Vander Zanden, J.M., 2006, Coupling long-term studies with meta-analysis to investigate impacts of non-native crayfish on zoobenthic communities: Freshwater Biology, v. 51, no. 2, p. 224-235.
McMahon, T.A., Brannelly, L.A., Chatfield, M.W., Johnson, P.T., Joseph, M.B., McKenzie, V.J., Richards-Zawacki, C.L., Venesky, M.D., and Rohr, J.R., 2013, Chytrid fungus Batrachochytrium dendrobatidis has nonamphibian hosts and releases chemicals that cause pathology in the absence of infection: Proceedings of the National Academy of Sciences of the United States of America, v. 110, no. 1, p. 210-215.

Meyer, J.Y., and Fourdrigniez, M., 2011, Conservation benefits of biological control-The recovery of a threatened plant subsequent to the introduction of a pathogen to contain an invasive tree species: Biological Conservation, v. 144, no. 1, p. 106-113.

Mummert, A.K., Neves, R.J., Newcomb, T.J., and Cherry, D.S., 2003, Sensitivity of juvenile freshwater mussels (Lampsilis fasciola, Villosa iris) to total and un-ionized ammonia: Environmental Toxicology and Chemistry: An International Journal, v. 22, no. 11, p. 2545-2553.

Nie, S., Ma, K., Sun, M., Lee, M., Tan, Y., Chen, G., and Cao, X., 2019, 7, 8-Dihydroxyflavone protects nigrostriatal dopaminergic neurons from rotenone-induced neurotoxicity in rodents: Parkinson's Disease, v. 2019, e. 9193534,

O’Grodnick, J.S., Wislocki, P.G., Keenan, K.P., Beavers, J.B., Frey, L.T., and Jaber, M., 1998, Subchronic and reproductive toxicity of emamectin benzoate to mallard ducks and northern bobwhite quail: Environmental Toxicology and Chemistry: An International Journal, v. 17, no. 11, p. 2318-2324.

Ogunsanya, T., Durborow, R.M., Webster, C.D., Tidwell, J.H., Coyle, S., Thompson, K., Jarboe, H.H., Straus, D.L., Wang, C., and Huang, L., 2011, Toxicity of rotenone to giant river freshwater prawn Macrobrachium rosenbergii: North American Journal of Aquaculture, v. 73, no. 2, p. 159-163.

Ojha, S., Javed, H., Azimullah, S., Khair, S.B.A., and Haque, M.E., 2015, Neuroprotective potential of ferulic acid in the rotenone model of Parkinson's disease: Drug Design, Development and Therapy, v. 9, p. 5499-5510.

O'Reilly, S., 2015, Assessing the toxicity of biocides on the North American signal crayfish Pacifastacus leniusculus (Dana) to aid eradication: Glasglow, Scotland, University of Glasgow, master's thesis, 172 p.

Overmyer, J.P., Rouse, D.R., Avants, J.K., Garrison, A.W., DeLorenzo, M.E., Chung, K.W., Key, P.B., Wilson, W.A., and Black, M.C., 2007, Toxicity of fipronil and its enantiomers to marine and freshwater non-targets: Journal of Environmental Science and Health. Part. B, Pesticides, Food Contaminants, and Agricultural Wastes, v. 42, no. 5, p. $471-480$. 
Palmquist, K., Salatas, J., and Fairbrother, A., 2012, Pyrethroid insecticides-Use, environmental fate, and ecotoxicology, in Benazir, S., ed., Insecticides-Advances in integrated pest management: London, England, Intech Open, p. 251-278. [Also available at https://www.intechopen.com/books/insecticides-advances-in-integrated-pest-management.]

Peay, S., 2001, Eradication of alien crayfish populations: Bristol, UK, R\&D Technical Report W1-037/TR1, p. 1-116.

Peay, S., Hiley, P.D., Collen, P., and Martin, I., 2006, Biocide treatment of ponds in Scotland to eradicate signal crayfish: Bulletin Français de la Pêche et de la Pisciculture, v. 2006, no. 380-381, p. 1363-1379. [Also available at https://www.kmae-journal.org/articles/kmae/abs/2006/01/ kmae200638035/kmae200638035.html.]

Perlman, D., 1973, Advances in applied microbiology v. 16: London, New York, Academic Press, p. 70-71.

Qu, H., Ma, R.X., Liu, D.H., Gao, J., Wang, F., Zhou, Z.Q., and Wang, P., 2016, Environmental behavior of the chiral insecticide fipronil-Enantioselective toxicity, distribution and transformation in aquatic ecosystem: Water Research, v. 105 , p. $138-146$.

Robertson, D.R., and Smith-Vaniz, W.F., 2008, Rotenone-An essential but demonized tool for assessing marine fish diversity: Bioscience, v. 58, no. 2, p. 165-170.

Roitzsch, M., Schäferhenrich, A., Baumgärtel, A., LudwigFischer, K., Hebisch, R., and Göen, T., 2019, Dermal and inhalation exposure of workers during control of oak processionary moth (OPM) by spray applications: Annals of Work Exposures and Health, v. 63, no. 3, p. 294-304.

Ros, D.R.O., An, D.S., Estuar, F., Oakland, C.A., and Werner, I., 2005, Pyrethroid Insecticides: An analysis of use patterns, distributions, potential toxicity and fate in the Sacramento-San Joaquin Delta and Central Valley: Oakland, CA, White Paper for the Interagency Ecological Program, p. $1-112$.

Rotherham, I., 2009, Exotic and non-native species: issues around alien, non-native, urban and problem species: Summary and overview: International Urban Ecology Review, no. 4, p. 6-9.

Sandodden, R., and Johnsen, S.I., 2010, Eradication of introduced signal crayfish Pasifastacus leniusculus using the pharmaceutical BETAMAX VET: Aquatic Invasions, v. 5, no. 1, p. $75-81$.

Saravanan, K.S., Sindhu, K.M., and Mohanakumar, K.P., 2005, Acute intranigral infusion of rotenone in rats causes progressive biochemical lesions in the striatum similar to Parkinson's disease: Brain Research, v. 1049, no. 2, p. 147-155.
Sargent, L.W., Baldridge, A.K., Vega-Ross, M., Towle, K.M., and Lodge, D.M., 2014, A trematode parasite alters growth, feeding behavior, and demographic success of invasive rusty crayfish (Orconectes rusticus): Oecologia, v. 175, no. 3, p. 947-958.

Schlenk, D., Huggett, D.B., Allgood, J., Bennett, E., Rimoldi, J., Beeler, A.B., Block, D., Holder, A.W., Hovinga, R., and Bedient, P., 2001, Toxicity of fipronil and its degradation products to Procambarus sp.-Field and laboratory studies: Archives of Environmental Contamination and Toxicology, v. 41, no. 3, p. 325-332.

Schuytema, G.S., 1977, Biological control of aquatic nuisances: a review: EPA report 600/3-77-087, p. 1-90.

Shanaman, L., and Carey, S., 2008, Environmental fate and ecological risk assessment of emamectin benzoate use on tree nuts and pistachios (New Use): EPA Memorandum. p. 1-303.

Simon-Delso, N., Amaral-Rogers, V., Belzunces, L.P., Bonmatin, J.M., Chagnon, M., Downs, C., Furlan, L., Gibbons, D.W., Giorio, C., Girolami, V., Goulson, D., Kreutzweiser, D.P., Krupke, C.H., Liess, M., Long, E., McField, M., Mineau, P., Mitchell, E.A., Morrissey, C.A., Noome, D.A., Pisa, L., Settele, J., Stark, J.D., Tapparo, A., Van Dyck, H., Van Praagh, J., Van der Sluijs, J.P., Whitehorn, P.R., and Wiemers, M., 2015, Systemic insecticides (neonicotinoids and fipronil)_-Trends, uses, mode of action and metabolites: Environmental Science and Pollution Research International, v. 22, no. 1, p. 5-34.

Sogorb, A., Andreu-Moliner, E.S., Almar, M.M., Del Ramo, J., and Nunez, A., 1988, Temperature-toxicity relationships of fluvalinate (synthetic pyrethroid) on Procambarus clarkii (Girard) under laboratory conditions: Bulletin of Environmental Contamination and Toxicology, v. 40, no. 1, p. 13-17.

Stark, J.D., and Vargas, R.I., 2005, Toxicity and hazard assessment of fipronil to Daphnia pulex: Ecotoxicology and Environmental Safety, v. 62, no. 1, p. 11-16.

Stebbing, P., Longshaw, M., and Scott, A., 2014, Review of methods for the management of non-indigenous crayfish, with particular reference to Great Britain: Ethology Ecology and Evolution, v. 26, no. 2-3, p. 204-231.

Sundaram, K.M.S., Sloane, L., and Nott, R., 1997, Adsorption and desorption kinetics of diflubenzuron and fenitrothion in two different boreal forest soils: Journal of Environmental Science and Health. Part. B, Pesticides, Food Contaminants, and Agricultural Wastes, v. 32, no. 1, p. 1-24.

Tarazona, J.V., Muńoz, M., Ortiz, J.A., Nunéz, M., and Camargo, J.A., 1987, Fish mortality due to acute ammonia exposure: Aquaculture Research, v. 18, no. 2, p. 167-172. 
Todd, G.D., Wohlers, D., and Citra, M.J., 2003, Toxicological profile for pyrethrins and pyrethroids: Atlanta, Georgia, U.S. Agency for Toxic Substances and Disease Registry, p. $1-287$.

Turner, L., Jacobson, S., and Shoemaker, L., 2007, Risk assessment for piscicidal formulations of antimycin: Lakewood, Washington, Compliance Services International for the Washington Department of Fish and Wildlife, p. 74.

Twardochleb, L.A., Olden, J.D., and Larson, E.R., 2013, A global meta-analysis of the ecological impacts of nonnative crayfish: Freshwater Science, v. 32, no. 4, p. 1367-1382.

U.S. Environmental Protection Agency (EPA), 2019, RF2232 LIQUID FT: EPA Application for Pesticide Notification under Pesticide Registration Notice (PRN) 98-10, 14 p. [Also available at https:/www3.epa.gov/pesticides/chem _ search/ppls/089459-00085-20191104.pdf].

U.S. Office of the Federal Register (USOFR), 2017, Data requirements for pesticides. Code of Federal Regulations, Title 40, Part 158: Washington, D.C., U.S. Government Printing Office, p. 1-873.

Waddy, S.L., Merritt, V.A., Hamilton-Gibson, M.N., and Aiken, D.E., 2010, Effect of emamectin benzoate on the molt cycle of ovigerous American lobsters Homarus americanus is influenced by the dosing regimen: Aquatic Biology, v. 11 , no. 1 , p. $47-52$.

Waddy, S.L., Merritt, V.A., Hamilton-Gibson, M.N., Aiken, D.E., and Burridge, L.E., 2007, Relationship between dose of emamectin benzoate and molting response of ovigerous American lobsters (Homarus americanus): Ecotoxicology and Environmental Safety, v. 67, no. 1, p. 95-99.

Walse, S.S., Pennington, P.L., Scott, G.I., and Ferry, J.L., 2004, The fate of fipronil in modular estuarine mesocosms: Journal of Environmental Monitoring, v. 6, no. 1, p. 58-64.

Wang, S., Li, H., and You, J., 2019, Enantioselective degradation and bioaccumulation of sediment-associated fipronil in Lumbriculus variegatus - Toxicokinetic analysis: The Science of the Total Environment, v. 672, p. 335-341.
Weston, D.P., Amweg, E.L., Mekebri, A., Ogle, R.S., and Lydy, M.J., 2006, Aquatic effects of aerial spraying for mosquito control over an urban area: Environmental Science \& Technology, v. 40, no. 18, p. 5817-5822.

Williams, R.L., Bernard, C.E., and Krieger, R.I., 2003, Human exposure to indoor residential cyfluthrin residues during a structured activity program: Journal of Exposure Science \& Environmental Epidemiology, v. 13, no. 2, p. 112-119.

Wise, L.D., Allen, H.L., Hoe, C.M.L., Verbeke, D.R., and Gerson, R.J., 1997, Developmental neurotoxicity evaluation of the avermectin pesticide, emamectin benzoate, in Sprague-Dawley rats: Neurotoxicology and Teratology, v. 19 , no. 4, p. 315-326.

Wolansky, M.J., Gennings, C., and Crofton, K.M., 2006, Relative potencies for acute effects of pyrethroids on motor function in rats: Toxicological Sciences, v. 89, no. 1, p. 271-277.

Wu, F., Xu, H.D., Guan, J.J., Hou, Y.S., Gu, J.H., Zhen, X.C., and Qin, Z.H., 2015, Rotenone impairs autophagic flux and lysosomal functions in Parkinson's disease: Neuroscience, v. 284 , p. 900-911.

Wu, H., Gao, C., Guo, Y., Zhang, Y., Zhang, J., and Ma, E., 2014, Acute toxicity and sublethal effects of fipronil on detoxification enzymes in juvenile zebrafish (Danio rerio): Pesticide Biochemistry and Physiology, v. 115, p. 9-14.

Wujtewicz, D., Petrosky, B.R., and Petrosky, D.L., 1997, Acute toxicity of 5\% non-synergized emulsifiable rotenone to white river crayfish Procambarus acutus acutus and white perch Morone americana: Journal of the World Aquaculture Society, v. 28, no. 3, p. 249-259.

Yang, W.C., Hunter, W., Spurlock, F., and Gan, J., 2007, Bioavailability of permethrin and cyfluthrin in surface waters with low levels of dissolved organic matter: Journal of Environmental Quality, v. 36, no. 6, p. 1678-1685. 


\section{Appendix 1. Search Terms for the "Literature Review for Candidate Control Agents for Nonnative Crayfish"}

This appendix presents keywords searched for the "Literature Review for Candidate Control Agents for Nonnative Crayfish" (table 1.1) The search produced 28,058 documents, which were then evaluated to determine if they contained information on physical, chemical, biological, and biocidal control approaches to crayfish control. Information on potential success as a crayfish control tool, environmental damage, application rate requirements (if applicable), exposure duration, nontarget effects, and environmental persistence were used as criteria to define which chemicals have the most potential to be tested as selective chemical crayfish control chemicals. Table is read as follows. The first keyword is the chemical name, either a product name or common name, used in publications for a specific compound. The next three keywords are combinations of words that are related to specific United States Environmental Protection Agency Guidelines. Databases searched include Web of Science and Scopus. 
Table 1.1. Search terms for the "Literature Review for Candidate Control Agents for Nonnative Crayfish."

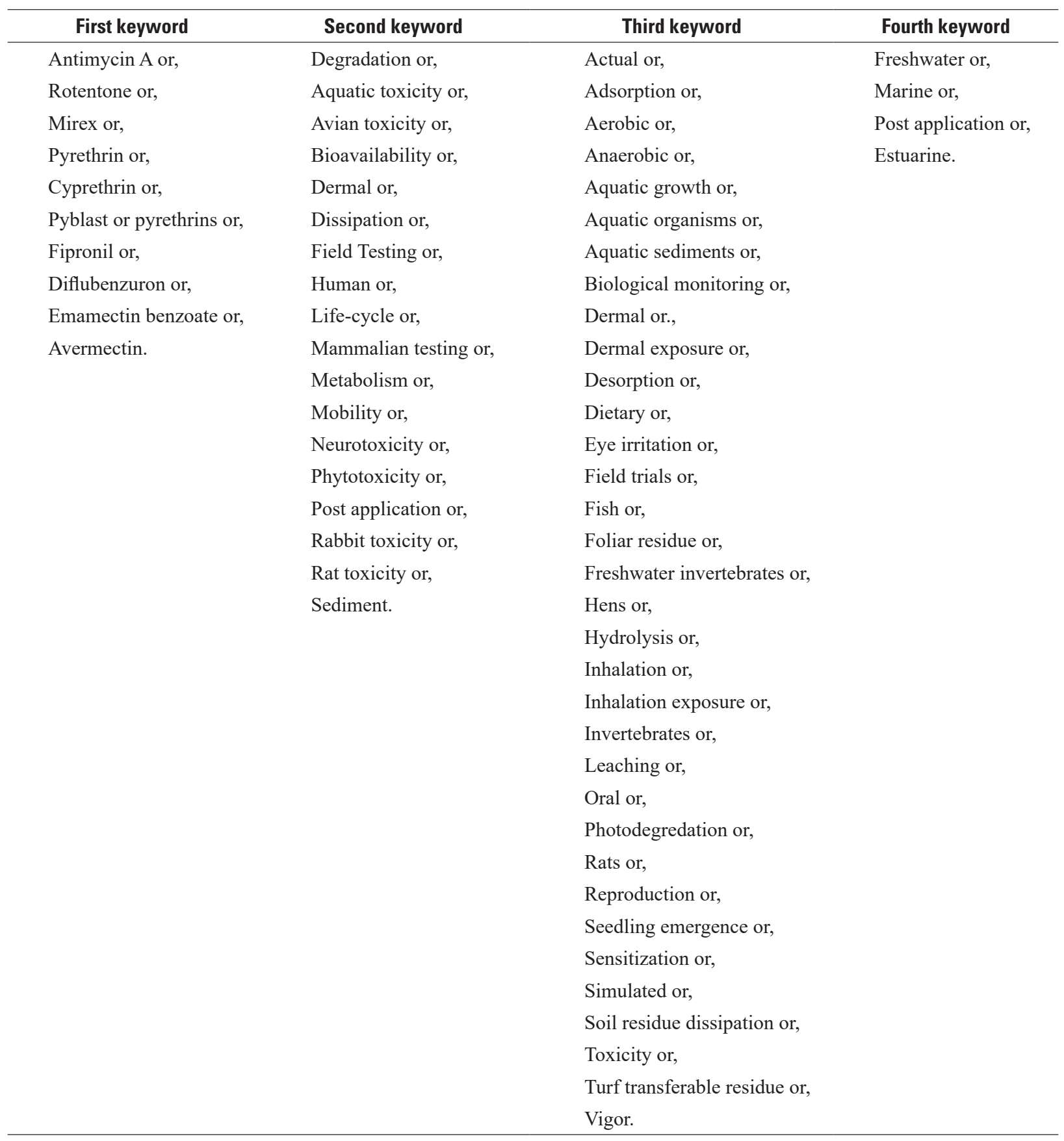




\section{Appendix 2. Chemical Properties and Toxicity Data as Determined from the "Literature Review for Candidate Control Agents for Nonnative Crayfish"}

Table 2.1. Pyblast toxicity to invasive Procambarus clarkia (red swamp) and Pacifastacus leniusculus (signal crayfish).

$\left[\mathrm{LC}_{50}\right.$, lethal concentration to produce fifty percent mortality; $\mu \mathrm{g} / \mathrm{L}$, micrograms per liter; hr, hour]

\begin{tabular}{lllc}
\hline \multicolumn{1}{c}{ Species } & \multicolumn{1}{c}{ Life stage } & LC $_{\mathbf{5 0}}$ & Concentration $(\boldsymbol{\mu g} / \mathbf{L})$ \\
\hline Signal crayfish $^{\text {a }}$ & Stage 1 hatchling & $48-\mathrm{hr}$ & 5.23 \\
Signal crayfish $^{\text {a }}$ & Stage 2 hatchling & $48-\mathrm{hr}$ & 6.43 \\
Signal crayfish $^{\text {a }}$ & Juvenile & $48-\mathrm{hr}$ & 57.95 \\
Signal crayfish $^{\text {a }}$ & Adult & $48-\mathrm{hr}$ & 118.25 \\
Red swamp $^{\text {b }}$ & Adult & $24-\mathrm{hr}$ & 50.0 \\
Red swamp $^{\text {b }}$ & Adult & $24-\mathrm{hr}$ & 20.0 \\
\hline
\end{tabular}

${ }^{a} O$ 'Reilly, 2015

${ }^{\mathrm{b}}$ Cecchinelli and others, 2012

Table 2.2. Pyblast toxicity to invertebrate and vertebrate nontarget aquatic species.

$\left[\mathrm{LC}_{50}\right.$, lethal concentration to produce fifty percent mortality; $\mu \mathrm{g} / \mathrm{L}$, micrograms per liter; $\mathrm{hr}$, hour $]$

\begin{tabular}{lllc}
\hline \multicolumn{1}{c}{ Species } & Common name & LC $_{\mathbf{5 0}}$ & Concentration ( $\mathbf{\mu g} / \mathbf{L})$ \\
\hline Daphnia magna $^{\text {a }}$ & Water flea & $48-\mathrm{hr}$ & 17.0 \\
Ictalurus punctatus $^{\mathrm{b}}$ & Channel catfish & $96-\mathrm{hr}$ & 114.0 \\
Lepomis macrochirus $^{\mathrm{b}}$ & Bluegill & $96-\mathrm{hr}$ & 49.0 \\
Oncorhynchus kisutch $^{\mathrm{b}}$ & Coho salmon & $96-\mathrm{hr}$ & 39.0 \\
Oncorhynchus mykiss $^{\mathrm{b}}$ & Rainbow trout & $96-\mathrm{hr}$ & 24.6 \\
Perca flavescens $^{\mathrm{b}}$ & Yellow perch & $96-\mathrm{hr}$ & $<50.1$ \\
\hline
\end{tabular}

${ }^{\mathrm{a}}$ Oikari and others, 1992

${ }^{\mathrm{b}}$ Mauck and others, 1976 
Table 2.3. Type-1 pyrethroid toxicity to Procambarus alleni (blue crayfish),

Procambarus blandingii (santee crayfish), Procambarus clarkii (red swamp crayfish), and Faxonius rusticus (rusty crayfish).

$\left[\mathrm{LC}_{50}\right.$, lethal concentration to produce fifty percent mortality; $\mu \mathrm{g} / \mathrm{L}$, micrograms per liter; hr, hour; N/A, life stage unavailable]

\begin{tabular}{|c|c|c|c|}
\hline Species & Life Stage & $\mathbf{L C}_{50}$ & Concentration( $\mu \mathrm{g} / \mathrm{L})$ \\
\hline Blue crayfish $^{a}$ & Juvenile & 96-hr & 0.58 \\
\hline Santee crayfish ${ }^{b}$ & $\mathrm{~N} / \mathrm{A}^{\mathrm{e}}$ & 96-hr & 0.21 \\
\hline Red Swamp crayfish ${ }^{c}$ & N/A & 96-hr & 0.28 \\
\hline Red Swamp crayfish ${ }^{\mathrm{d}}$ & New Hatch & 96-hr & 0.39 \\
\hline Red Swamp crayfish $^{d}$ & Juvenile & 96-hr & 0.62 \\
\hline Red Swamp crayfish ${ }^{d}$ & Adult & 24-hr & 0.49 \\
\hline Rusty crayfish $^{\mathrm{d}}$ & N/A & 96-hr & $<1.2$ \\
\hline
\end{tabular}

${ }^{\mathrm{a}}$ Halstead and others, 2015

${ }^{\mathrm{b}}$ Fojut and others, 2012

${ }^{\mathrm{c}}$ Schleier and Peterson, 2013

${ }^{\mathrm{d} O}$ 'Reilly, 2015 
Table 2.4. Type-1 pyrethroids toxicity to invertebrate and vertebrate nontarget aquatic species. Toxicity data is for permethrin only.

$\left[\mathrm{LC}_{50}\right.$, lethal concentration to produce fifty percent mortality; $\mu \mathrm{g} / \mathrm{L}$, micrograms per liter; hr, hour]

\begin{tabular}{|c|c|c|c|}
\hline Species & Common name & $\mathbf{L C}_{50}$ & Concentration( $\mu \mathrm{g} / \mathrm{L})$ \\
\hline Ceriodaphnia dubia ${ }^{\mathrm{a}}$ & Water flea & 96-hr & 0.57 \\
\hline Chironomus dilutes $^{\mathrm{b}}$ & Midge & 96-hr & 0.189 \\
\hline Daphnia magna ${ }^{\mathrm{c}}$ & Water flea & 96-hr & 0.3 \\
\hline Daphnia magna ${ }^{\mathrm{d}}$ & Water flea & $48-\mathrm{hr}$ & 0.32 \\
\hline Hyalella Azteca ${ }^{\mathrm{e}}$ & Crustacea & 96-hr & 0.211 \\
\hline Danio rerio ${ }^{\mathrm{f}}$ & Zebrafish & 96-hr & 2.50 \\
\hline Erimonax monachus ${ }^{\mathrm{g}}$ & Chub & 96-hr & 1.7 \\
\hline Etheostoma fonticola ${ }^{\mathrm{g}}$ & Darter & 96-hr & 3.34 \\
\hline Etheostoma lepidum ${ }^{\mathrm{g}}$ & Darter & 96-hr & 2.71 \\
\hline Ictalurus punctatus $^{\mathrm{h}}$ & Channel catfish & 96-hr & 5.4 \\
\hline Lepomis macrochirus $^{\mathrm{d}}$ & Bluegill & 96-hr & 2.52 \\
\hline Menidia menidia $^{\mathrm{d}}$ & Atlantic silverside & 96-hr & 2.2 \\
\hline Notropis mekistocholas ${ }^{\mathrm{g}}$ & Shiner & 96-hr & 4.16 \\
\hline Oncorhynchus apache ${ }^{\mathrm{g}}$ & Apache trout & 96-hr & 1.71 \\
\hline Salvelinus fontinalis ${ }^{\mathrm{j}}$ & Brook trout & 24-hr & 4.80 \\
\hline Salvelinus fontinalis ${ }^{\mathrm{j}}$ & Brook trout & $48-\mathrm{hr}$ & 3.03 \\
\hline Salvelinus fontinalis ${ }^{\mathrm{j}}$ & Brook trout & 96-hr & 2.86 \\
\hline Oncorhynchus clarki ${ }^{\mathrm{c}}$ & Cutthroat trout & 96-hr & 1.58 \\
\hline Oncorhynchus mykiss ${ }^{\mathrm{i}}$ & Rainbow trout & 96-hr & 7.0 \\
\hline Oncorhynchus mykiss ${ }^{\mathrm{d}}$ & Rainbow trout & 96-hr & 0.62 \\
\hline Pimephales promelas ${ }^{\mathrm{c}}$ & Fathead minnow & 96-hr & 3.0 \\
\hline Pimephales promelas ${ }^{\mathrm{d}}$ & Fathead minnow & 96-hr & 3.5 \\
\hline Salmo salar ${ }^{\mathrm{h}}$ & Atlantic salmon & 96-hr & 1.5 \\
\hline Xyrauchen texanus ${ }^{\mathrm{g}}$ & Sucker & 96-hr & 5.95 \\
\hline
\end{tabular}

${ }^{a}$ Yang and others, 2007

${ }^{\mathrm{b}}$ Harwood and others, 2009

${ }^{\mathrm{c}}$ Schleier and Peterson, 2013

${ }^{\mathrm{d}}$ Finto, 1990

${ }^{\mathrm{e}}$ Anderson and others, 2006

${ }^{\mathrm{f}}$ Zhang and others, 2010

${ }^{\mathrm{g}}$ Dwyer and others, 2005

${ }^{\mathrm{h}}$ Fojut and others, 2012

${ }^{\mathrm{i}}$ Holcombe and others, 1982

${ }^{\mathrm{j}}$ Paul and others, 2005 
Table 2.5. Type-2 pyrethroids toxicity to crayfish at various life stages. Data for four type-2 pyrethroids is displayed for Procambarus clarkii (red swamp crayfish), Procambarus alleni (blue crayfish), and Pacifastacus leniusculus (signal crayfish).

$\left[\mathrm{LC}_{50}\right.$, lethal concentration to produce fifty percent mortality; $\mu \mathrm{g} / \mathrm{L}$, micrograms per liter; hr, hour]

\begin{tabular}{|c|c|c|c|c|}
\hline Species & Life Stage & Chemical & $\mathbf{L C}_{50}$ & Concentration $(\mu \mathrm{g} / \mathrm{L})$ \\
\hline Red swamp crayfish ${ }^{\text {a }}$ & Adult & Cyfluthrin & 24-hr & 0.17 \\
\hline Red swamp crayfish ${ }^{a}$ & Adult & Cyfluthrin & $48-\mathrm{hr}$ & 0.08 \\
\hline Blue crayfish ${ }^{b}$ & Juvenile & Cyhalothrin & 96-hr & 0.21 \\
\hline Red swamp crayfish $^{c}$ & Juvenile & Cyhalothrin & $96-\mathrm{hr}$ & 0.16 \\
\hline Red swamp crayfish ${ }^{a}$ & Adult & Cypermethrin & 24-hr & 0.14 \\
\hline Red swamp crayfish ${ }^{a}$ & Adult & Cypermethrin & 48-hr & 0.10 \\
\hline Red swamp crayfish ${ }^{a}$ & Adult & Deltamethrin & 24-hr & 0.22 \\
\hline Red swamp crayfish ${ }^{a}$ & Adult & Deltamethrin & 48-hr & 0.18 \\
\hline Red swamp crayfish ${ }^{d}$ & Adult & Deltamethrin & 24-hr & 0.156 \\
\hline Red swamp crayfish ${ }^{\mathrm{d}}$ & Adult & Deltamethrin & $48-\mathrm{hr}$ & 0.099 \\
\hline Red swamp crayfish ${ }^{d}$ & Adult & Deltamethrin & 96-hr & 0.056 \\
\hline Signal crayfish ${ }^{\mathrm{e}}$ & Adult & Deltamethrin & 48-hr & 0.86 \\
\hline
\end{tabular}

${ }^{\mathrm{a}}$ Morolli and others, 2006

${ }^{\mathrm{b}}$ Halstead and others, 2015

${ }^{c}$ Barbee and Stout, 2009

${ }^{\mathrm{d}} \mathrm{Wu}$ and others, 2012

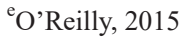

Table 2.6. Fluvalinate toxicity to adult Procambarus clarkii (red swamp crayfish) with differing water conditions (Sorgorb and others, 1988). Toxicity test results are displayed as a 96-hour lethal concentration to produce fifty percent mortality in test species $\left(\mathrm{LC}_{50}\right)$ values.

$\left[{ }^{\circ} \mathrm{C}\right.$, degrees celcius; $\mu \mathrm{g} / \mathrm{L}$, micrograms per liter; $]$

\begin{tabular}{clc}
\hline $\begin{array}{c}\text { Temperature } \\
\left({ }^{\circ} \mathbf{C}\right)\end{array}$ & Medium $^{\mathrm{a}}$ & $\begin{array}{c}\text { Concentration } \\
(\boldsymbol{\mu g} / \mathbf{L})\end{array}$ \\
\hline 12 & Laboratory & 0.51 \\
18 & Laboratory & 0.46 \\
22 & Laboratory & 0.31 \\
27 & Laboratory & 0.23 \\
12 & Field & 1.08 \\
18 & Field & 0.72 \\
22 & Field & 0.64 \\
27 & Field & 0.50 \\
\hline
\end{tabular}

${ }^{\mathrm{a}}$ Medium refers to whether the tests were completed in lab water (experimental) or in natural water environment. 
Table 2.7. Type-2 pyrethroid lethal concentration to produce fifty percent mortality in test species $\left(\mathrm{LC}_{50}\right)$ concentrations for nontarget aquatic species. Three type-2 pyrethroids toxicity data is reported. The table is grouped by invertebrate or fish, and then chemical.

[ $\mathrm{LC}_{50}$, lethal concentration to produce fifty percent mortality; $\mu \mathrm{g} / \mathrm{L}$, micrograms per liter; hr, hour]

\begin{tabular}{|c|c|c|c|c|}
\hline Species & Common name & Chemical & $\mathbf{L C}_{50}$ & Concentration $(\mu \mathrm{g} / \mathrm{L})$ \\
\hline Ceriodaphnia dubia ${ }^{\mathrm{a}}$ & Water flea & Cyfluthrin & 96-hr & 0.105 \\
\hline Daphnia magna ${ }^{\mathrm{b}}$ & Water flea & Cyfluthrin & 96-hr & 0.16 \\
\hline Daphnia magna ${ }^{\mathrm{c}}$ & Water flea & Cyfluthrin & $48-\mathrm{hr}$ & 0.14 \\
\hline Hyalella Azteca ${ }^{\mathrm{d}}$ & Scud & Cyfluthrin & 96-hr & 0.017 \\
\hline Hyalella Azteca ${ }^{\mathrm{e}}$ & Scud & Cyfluthrin & 96-hr & 0.0015 \\
\hline Ceriodaphnia dubia ${ }^{\mathrm{f}}$ & Water flea & Cyhalothrin & 96-hr & 0.200 \\
\hline Gammarus pulex ${ }^{\mathrm{b}}$ & Scud & Cyhalothrin & 96-hr & 0.0059 \\
\hline Ceriodaphnia dubia ${ }^{\mathrm{f}}$ & Water flea & Cypermethrin & 48-hr & 0.683 \\
\hline Daphnia magna $^{\mathrm{b}}$ & Water flea & Cypermethrin & $48-\mathrm{hr}$ & 0.161 \\
\hline Lepomis macrochirus ${ }^{\mathrm{c}}$ & Bluegill & Cyfluthrin & 96-hr & 0.68 \\
\hline Oncorhynchus mykiss ${ }^{\mathrm{c}}$ & Rainbow trout & Cyfluthrin & 96-hr & 1.5 \\
\hline Oncorhynchus mykiss ${ }^{\mathrm{b}}$ & Rainbow trout & Cyfluthrin & 96-hr & 2.09 \\
\hline Pimephales promelas ${ }^{\mathrm{b}}$ & Fathead minnow & Cyfluthrin & 96-hr & 2.49 \\
\hline Pimephales promelas $\mathrm{e}$ & Fathead minnow & Cyfluthrin & 96-hr & 0.31 \\
\hline Brachydanio rerio $^{\mathrm{b}}$ & Zebrafish & Cyhalothrin & 96-hr & 0.64 \\
\hline Gasterosteus aculeatus $^{\mathrm{b}}$ & Stickleback & Cyhalothrin & 96-hr & 0.40 \\
\hline Ictalurus punctatus $^{\mathrm{b}}$ & Channel catfish & Cyhalothrin & 96-hr & 0.16 \\
\hline Lepomis machrochirus ${ }^{\mathrm{b}}$ & Bluegill & Cyhalothrin & 96-hr & 0.106 \\
\hline Leucisus idus ${ }^{\mathrm{b}}$ & Ide & Cyhalothrin & 96-hr & 0.078 \\
\hline Oncorhynchus mykiss ${ }^{\mathrm{b}}$ & Rainbow trout & Cyhalothrin & 96-hr & 0.19 \\
\hline Pimephales promelas ${ }^{\mathrm{b}}$ & Fathead minnow & Cyhalothrin & 96-hr & 0.360 \\
\hline Oncorhynchus mykiss ${ }^{\mathrm{b}}$ & Rainbow trout & Cypermethrin & 96-hr & 0.90 \\
\hline
\end{tabular}

${ }^{\mathrm{a}}$ Yang and others, 2007

${ }^{\mathrm{b}}$ Fojut and others, 2012

${ }^{\mathrm{c}}$ Finto, 1990

${ }^{\mathrm{d}}$ Weston and Jackson, 2009

${ }^{\mathrm{e}}$ Lanteigne and others, 2015

${ }^{\mathrm{f}}$ Wheelock and others, 2004

Table 2.8. Type-1 and 2 pyrethroid degradation data (Laskowski, 2002; Dobbs and others, 2007; Fojut and others, 2010).

\begin{tabular}{lllccc}
\hline \multirow{2}{*}{ Chemical } & \multicolumn{3}{c}{ Hydrolysis half-life (days) } & $\begin{array}{c}\text { Water photolysis } \\
\text { half-life (days) }\end{array}$ & $\begin{array}{c}\text { Soil photolysis } \\
\text { half-life (days) }\end{array}$ \\
\cline { 2 - 5 } & $\mathbf{p H ~ 5}$ & $\mathbf{p H ~ 7}$ & $\mathbf{p H ~ 9}$ & 0.67 & 5 \\
\hline Cyfluthrin & Stable & 183 & 1.8 & 25 & 54 \\
Cyhalothrin & Stable & Stable & 8.7 & 30 & 165 \\
Cypermethrin & 619 & 274 & 1.9 & 56 & 35 \\
Deltamethrin & Stable & Stable & 2.2 & 110 & 104 \\
Permethrin & Stable & Stable & 242.0 & \multicolumn{2}{c}{} \\
\hline
\end{tabular}


Table 2.9. Physical chemistry data for Type-1 and 2 pyrethroids (Laskowski, 2002).

$\left[\log \mathrm{P}^{\mathrm{a}}\right.$, partition coefficient, ratio of chemical bound to organic phase $(\log \mathrm{P})$ verses aqueous phase, a higher positive number meaning the chemical concentrates in the lipid phase; $\mu \mathrm{g} / \mathrm{L}$, micrograms per liter; $\mathrm{BCF}$, bioconcentration factor in fish (BCF) tissue compared to water concentration; Koc, soil absorption coefficient]

\begin{tabular}{lccccc}
\hline \multicolumn{1}{c}{ Chemical } & $\begin{array}{c}\text { Molecular } \\
\text { weight }\end{array}$ & LogP & Koc (soil sorption) & $\begin{array}{c}\text { Water solubility } \\
\text { ( } \mathbf{g} / \mathbf{L})\end{array}$ & BCF (Fish) \\
\hline Cyfluthrin & 434.3 & 5.97 & 124000 & 2.3 & 719 \\
Cyhalothrin & 449.9 & 7.00 & 326000 & 5.0 & 2240 \\
Cypermethrin & 416.3 & 6.54 & 310000 & 4.0 & 597 \\
Deltamethrin & 505.2 & 4.53 & 704000 & 2.0 & 698 \\
Permethrin & 391.3 & 6.10 & 277000 & 5.5 & 558 \\
\hline
\end{tabular}

Table 2.10. Selective cyanobacteria and green algae 96-hour exposure response to beta-cyfluthrin (Ma, 2005).

$\left[\mathrm{EC}_{50}\right.$, effective concentration to produce effect in fifty percent of individuals; LOEC, lowest observable effect concentration; NOEC, no observable effect concentration; $\mathrm{mg} / \mathrm{L}$, milligrams per liter]

\begin{tabular}{|c|c|c|c|}
\hline Species & $\mathrm{EC}_{50}(\mathrm{mg} / \mathrm{L})$ & LOEC (mg/L) & NOEC (mg/L) \\
\hline Anabaena flos-aquae & 62.3 & 25 & 10 \\
\hline Microcystis flos-aquae & 87.0 & 10 & 5 \\
\hline Mirocystis aeruginosa & 34.6 & 20 & 10 \\
\hline Selenastrum capricornutun & 3.4 & 0.5 & 0.2 \\
\hline Scenedesmus quadricauda & 2.4 & 0.5 & 0.2 \\
\hline Scenedesmus obliqnus & 97.0 & 10 & 5 \\
\hline Chlorella vulgaris & 4.4 & 0.5 & 0.2 \\
\hline Chlorella pyrenoidosa & 885.2 & 20 & 10 \\
\hline
\end{tabular}


Table 2.11. Toxicity of fipronil and its breakdown products to Procambarus zonangulus (Southern White River [SWR] crayfish), Procambarus clarkii (red swamp crayfish), and Palaemonetes pugio (grass shrimp).

$\left[\mathrm{LC}_{50}\right.$, lethal concentration to produce fifty percent mortality; $\mu \mathrm{g} / \mathrm{L}$, micrograms per liter; hr, hour]

\begin{tabular}{cllc}
\hline \multicolumn{1}{c}{ Species } & Age & Chemical & $\begin{array}{c}\text { Concentration } \\
(\boldsymbol{\mu} \mathbf{g} / \mathbf{L})\end{array}$ \\
\hline SWR Crayfish $^{\text {a }}$ & Juvenile & Fipronil & 19.5 \\
Red swamp $^{\text {a }}$ & Juvenile & Fipronil & 14.3 \\
Red swamp $^{\text {a }}$ & Juvenile & Fipronil Sulphone & 11.2 \\
Red swamp $^{\text {a }}$ & Juvenile & Fipronil Sulfide & 15.5 \\
Red swamp $^{\text {a }}$ & Juvenile & Desulfinyl fipronil & 68.6 \\
Red swamp $^{\text {b }}$ & Adult & Fipronil & 180 \\
Red swamp $^{\text {c }}$ & Adult & Fipronil $(+)$ & 81.7 \\
Red swamp $^{\text {c }}$ & Adult & Fipronil $(-)$ & 163.5 \\
Red swamp $^{\text {c }}$ & Adult & Fipronil $( \pm)$ & 124.9 \\
Grass shrimp $^{\text {d }}$ & Embryo & Fipronil & $>512.0$ \\
Grass shrimp $^{\text {d }}$ & Larvae & Fipronil & 0.68 \\
Grass shrimp $^{\text {d }}$ & Adult & Fipronil & 0.32 \\
\hline
\end{tabular}

${ }^{\mathrm{a}}$ Schlenk and others, 2001

${ }^{\mathrm{b}}$ Biever and others, 2003

'Overmyer and others, 2007

${ }^{\mathrm{d}}$ Key and others, 2003 
Table 2.12. Toxicity of fipronil and its breakdown products to nontarget aquatic species.

$\left[\mathrm{LC}_{50}\right.$, lethal concentration to produce fifty percent mortality; $\mu \mathrm{g} / \mathrm{L}$, micrograms per liter; hr, hour $]$

\begin{tabular}{|c|c|c|c|c|}
\hline Species & Common name & Chemical & $\mathbf{L C}_{50}$ & $\begin{array}{c}\text { Concentration } \\
(\mu \mathrm{g} / \mathrm{L})\end{array}$ \\
\hline Ceriodaphnia dubia $^{a}$ & Water flea & Fipronil & $48-\mathrm{hr}$ & 17.7 \\
\hline Ceriodaphnia dubia $^{a}$ & Water flea & Fipronil (+) & $48-\mathrm{hr}$ & 10.3 \\
\hline Ceriodaphnia dubia $^{a}$ & Water flea & Fipronil (-) & $48-\mathrm{hr}$ & 31.9 \\
\hline Ceriodaphnia dubia $^{a}$ & Water flea & Defulfinyl fipronil & $48-\mathrm{hr}$ & 355 \\
\hline Daphnia magna $^{b}$ & Water flea & Fipronil & 24-hr & 240 \\
\hline Daphnia pulex ${ }^{c}$ & Water flea & Fipronil & $48-\mathrm{hr}$ & 15.6 \\
\hline Hyalella Azteca ${ }^{d}$ & Scud & Fipronil & 96-hr & 1.593 \\
\hline Hyalella Azteca ${ }^{\mathrm{d}}$ & Scud & Fipronil sulphone & 96-hr & 0.748 \\
\hline Hyalella Azteca $^{\mathrm{d}}$ & Scud & Fipronil sulfide & 96-hr & 1.359 \\
\hline Palaemonetes pugio ${ }^{\mathrm{e}}$ & Grass shrimp & Fipronil & 96-hr & 320 \\
\hline Danio rerio $^{\mathrm{b}}$ & Zebrafish & Fipronil & 24-hr & 220.4 \\
\hline Lepomis macrochirus ${ }^{\mathrm{f}}$ & Bluegill & Fipronil & 24-hr & 83 \\
\hline Oncorhynchus mykiss ${ }^{\mathrm{f}}$ & Rainbow trout & Fipronil & 24-hr & 246 \\
\hline Pimephales promelas ${ }^{\mathrm{g}}$ & Fathead minnow & Fipronil & 24-hr & 398 \\
\hline Pimephales promelas ${ }^{\mathrm{h}}$ & Fathead minnow & Fipronil & 96-hr & 450 \\
\hline
\end{tabular}

${ }^{\mathrm{a}}$ Konwick and others, 2005

${ }^{\mathrm{b}} \mathrm{Wu}$ and others 2014

${ }^{\mathrm{c}}$ Stark and Vargas, 2005

${ }^{\mathrm{d}}$ Weston and Lydy, 2014

${ }^{\mathrm{e}}$ Key and others, 2003

${ }^{\mathrm{f}}$ Maciorowski, 1994

${ }^{g}$ Beggel and others, 2010

${ }^{\mathrm{h}}$ Baird and others, 2013

Table 2.13. Summarized data on fipronil degradation and physical chemical properties (Gunasekara and others, 2007). Molecular weight is reported in grams per mole $(\mathrm{g} / \mathrm{mol})$. Solubility is reported as milligrams per liter ( $\mathrm{mg} / \mathrm{L})$.

[g/mol, grams per mole; mg/L, milligrams per liter; Koc, soil absorption coefficient]

\begin{tabular}{ll}
\hline \multicolumn{1}{c}{ Environmental properties } & \multicolumn{1}{c}{ Values } \\
\hline pH 5.5 half-life & $>100$ days \\
pH 7.0 half-life & $>100$ days \\
pH 9.0 half-life & 32.08 days \\
Aqueous photolysis half-life & 0.33 days \\
Molecular weight & $473.2 \mathrm{~g} / \mathrm{mol}$ \\
Solubility & $1.90-2.40 \mathrm{mg} / \mathrm{L}$ \\
Koc & 825 \\
\hline
\end{tabular}


Table 2.14. Toxicity diflubenzuron to aquatic species. Three species of crab and shrimp are used as crayfish surrogates. Additional toxicity data was available for a copepod and for zebrafish.

$\left[\mathrm{LC}_{50}\right.$, lethal concentration to produce fifty percent mortality; $\mu \mathrm{g} / \mathrm{L}$, micrograms per liter; hr, hour]

\begin{tabular}{|c|c|c|c|}
\hline Species & Species type & $\mathbf{L C}_{50}$ & Concentration $(\mu \mathrm{g} / \mathrm{L})$ \\
\hline Rhithropanopens harrisii ${ }^{\text {a }}$ & Mud crab (larvae) & $48-\mathrm{hr}$ & 10 \\
\hline Mysidopsis bahia ${ }^{\mathrm{b}}$ & Mysid shrimp & 96-hr & 2.1 \\
\hline Palaemonetes pugio ${ }^{\mathrm{c}}$ & Grass shrimp (larvae) & $96-\mathrm{hr}$ & 1.44 \\
\hline Palaemonetes pugio ${ }^{\mathrm{c}}$ & Grass shrimp (adult) & $96-\mathrm{hr}$ & $>200$ \\
\hline Eurytemore affinis ${ }^{\mathrm{d}}$ & Copepod & $48-\mathrm{hr}$ & 2.2 \\
\hline Danio rerio $^{\mathrm{e}}$ & Fish (zebrafish) & 96-hr & $>200$ \\
\hline
\end{tabular}

${ }^{a}$ Christiansen and others, 1978

${ }^{\mathrm{b}}$ Nimmo and others 1979

${ }^{\mathrm{c}}$ Wilson and Costlow, 1987

${ }^{\mathrm{d}}$ Savitz and others, 1994

${ }^{\mathrm{e}}$ Doucet and Retnakaran, 2012

Table 2.15. Absorption and desorption values for diflubenzuron. Soil pH was 5.5 and temperature was $20^{\circ} \mathrm{C}$. Soil samples collected from boreal forests in Northern Ontario, Canada (Sundaram and others, 1997).

$[\mu \mathrm{g} / \mathrm{g}$, micrograms per gram; hr, hour]

\begin{tabular}{lccc}
\hline \multicolumn{1}{c}{ Soil type } & $\begin{array}{c}\text { Adsorption } \\
\text { mass }(\boldsymbol{\mu g} / \mathbf{g})\end{array}$ & $\begin{array}{c}\text { Maximum } \\
\text { adsorption }(\mathbf{h r})\end{array}$ & $\begin{array}{c}\text { Desorption } \\
\text { percent }(\%)\end{array}$ \\
\hline Organic soil & $73-88$ & 18 & $16-27$ \\
Silty clay loam & $81-92$ & 24 & $16-27$ \\
\hline
\end{tabular}

Table 2.16. Toxicity of antimycin-A to crayfish. Toxicity test results are displayed as a 96-hour lethal concentration to produce fifty percent mortality in test species $\left(\mathrm{LC}_{50}\right)$ values. Molted crayfish have lower $\mathrm{LC}_{50}$ values. Smaller juvenile crayfish have lower $\mathrm{LC}_{50}$ values.

$[\mathrm{mm}$, millimeter; $\mu \mathrm{g} / \mathrm{L}$, microgram per liter; N/A, life stage unavailable; Data was obtained from the U.S. Environmental Protection Agency ECOTOX database]

\begin{tabular}{|c|c|c|c|c|}
\hline Species & Age & $\begin{array}{l}\text { Size } \\
(\mathrm{mm})\end{array}$ & Molted & $\begin{array}{c}\text { Concentration } \\
(\mu \mathrm{g} / \mathrm{L})\end{array}$ \\
\hline Cambarus sp. ${ }^{\mathrm{a}}$ & N/A & $\mathrm{N} / \mathrm{A}$ & N/A & 10 \\
\hline Procambarus sp. ${ }^{\mathrm{b}}$ & Juvenile & 8 & No & 68 \\
\hline Procambarus sp. ${ }^{\mathrm{b}}$ & Juvenile & 8 & Yes & 39 \\
\hline Procambarus sp. ${ }^{\mathrm{b}}$ & Juvenile & 19 & No & 168 \\
\hline Procambarus sp. ${ }^{\mathrm{b}}$ & Juvenile & 19 & Yes & 60 \\
\hline Procambarus sp. ${ }^{\mathrm{b}}$ & Juvenile & 30 & No & 735 \\
\hline Procambarus sp. ${ }^{\mathrm{b}}$ & Juvenile & 30 & Yes & 175 \\
\hline
\end{tabular}


Table 2.17. Toxicity of antimycin-A to nontarget aquatic species (Turner and others, 2007).

[ $\mathrm{LC}_{50}$, lethal concentration to produce fifty percent mortality; $\mu \mathrm{g} / \mathrm{L}$, micrograms per liter; hr, hour]

\begin{tabular}{llc}
\hline \multicolumn{1}{c}{ Species } & Species type & Concentration $(\boldsymbol{\mu g} / \mathbf{L})$ \\
\hline Chironomus tentans & Midge & 0.146 \\
Gammarus pseudolimnaeus & Scud & 9.0 \\
Hyalella azteca & Scud & 1.4 \\
Carassius auratus & Goldfish & 0.18 \\
Lepomis macrochirus & Bluegill & 0.034 \\
Lepomis cyanella & Sunfish & 0.22 \\
Oncorhynchus mykiss & Rainbow trout & 0.012 \\
Oncorhynchus clarki & Cutthroat trout & 0.057 \\
Pimephales promelas & Fathead minnow & 0.025 \\
Perca flavescens & Yellow perch & 0.04 \\
\hline
\end{tabular}

Table 2.18. Summarized data on emamectin benzoate's environmental properties (Shanaman and Carey, 2008).

[g/mol; grams per mole]

\begin{tabular}{ll}
\hline \multicolumn{1}{c}{ Environmental properties } & Value \\
\hline Aquatic photolysis half-life & 23 Days \\
Soil photolysis & 5 Days \\
Hydrolysis pH 5-8 half-life & Stable \\
Hydrolysis pH 9 half-life & 20 weeks \\
Soil water partition coefficient Koc & 265687 \\
Molecular weight & $964 \mathrm{~g} / \mathrm{mol}$ \\
Aerobic aquatic metabolism half-life & 193 days \\
Anaerobic aquatic metabolism half-life & 427 days \\
\hline
\end{tabular}




\section{References Cited}

Anderson, B.S., Phillips, B.M., Hunt, J.W., Connor, V., Richard, N., and Tjeerdema, R.S., 2006, Identifying primary stressors impacting macroinvertebrates in the Salinas River (California, USA)-Relative effects of pesticides and suspended particles: Environmental Pollution, v. 141, no. 3, p. 402-408.

Baird, S., Garrison, A., Jones, J., Avants, J., Bringolf, R., and Black, M., 2013, Enantioselective toxicity and bioaccumulation of fipronil in fathead minnows (Pimephales promelas) following water and sediment exposures: Environmental Toxicology and Chemistry, v. 32, no. 1, p. 222-227.

Barbee, G.C., and Stout, M.J., 2009, Comparative acute toxicity of neonicotinoid and pyrethroid insecticides to non-target crayfish (Procambarus clarkii) associated with rice-crayfish crop rotations-Pest Management Science, formerly: Pesticide Science, v. 65, no. 11, p. 1250-1256.

Beggel, S., Werner, I., Connon, R.E., and Geist, J.P., 2010, Sublethal toxicity of commercial insecticide formulations and their active ingredients to larval fathead minnow (Pimephales promelas): The Science of the Total Environment, v. 408, no. 16, p. 3169-3175.

Biever, R.C., Hoberg, J.R., Jacobson, B., Dionne, E., Sulaiman, M., and McCahon, P., 2003, Icon ${ }^{\circledR}$ rice seed treatment toxicity to crayfish (Procambarus clarkii) in experimental rice paddies: Environmental Toxicology and Chemistry: An International Journal, v. 22, no. 1, p. 167-174.

Brown, R.T., and Avault James Jr, W., 1975, Toxicity of antimycin to crayfish, Procambarus spp: Freshwater Crayfish, v. 2, p. 351-370.

Cecchinelli, E., Aquiloni, L., Maltagliati, G., Orioli, G., Tricarico, E., and Gherardi, F., 2012, Use of natural pyrethrum to control the red swamp crayfish Procambarus clarkii in a rural district of Italy-Pest Management Science, formerly: Pesticide Science, v. 68, no. 6, p. 839-844.

Christiansen, M.E., Costlow, J.D., Jr., and Monroe, R.J., 1978, Effects of the insect growth regulator Dimilin ${ }^{\circledR}$ (TH 6040) on larval development of two estuarine crabs: Marine Biology, v. 50, no. 1, p. 29-36.

Dobbs, M., Warinton, J., Giddings, J., Hendley, P., and Lam, C., 2007, Environmental Fate and Aquatic Toxicology of Synthetic Pyrethroids: Pyrethroid Working Group, presentation at California DPR Pyrethroid Forum, April 30, 2007.

Doucet, D., and Retnakaran, A., 2012, Chapter Six - Insect chitin-Metabolism, genomics and pest management: Advances in Insect Physiology, v. 43, p. 437-511.
Dwyer, F.J., Mayer, F.L., Sappington, L.C., Buckler, D.R., Bridges, C.M., Greer, I.E., Hardesty, D.K., Henke, C.E., Ingersoll, C.G., Kunz, J.L., Whites, D.W., Augspurger, T., Mount, D.R., Hattala, K., and Neuderfer, G.N., 2005, Assessing contaminant sensitivity of endangered and threatened aquatic species-Part I. Acute toxicity of five chemicals: Archives of Environmental Contamination and Toxicology, v. 48, no. 2, p. 143-154.

Fojut, T.L., Chang, S., and Tjeerdema, R.S., 2010, Water quality criteria report for cyfluthrin. Phase III-Application of the pesticide water quality criteria methodology. Central Valley Regional Water Quality Control Board, p. 1-40.

Fojut, T.L., Palumbo, A.J., and Tjeerdema, R.S., 2012, Aquatic life water quality criteria derived via the UC Davis method-II. Pyrethroid insecticides: Reviews of Environmental Contamination and Toxicology, v. 216, p. 51-103.

Gunasekara, A.S., Truong, T., Goh, K.S., Spurlock, F., and Tjeerdema, R.S., 2007, Environmental fate and toxicology of fipronil: Journal of Pesticide Science, v. 32, no. 3, p. 189-199.

Halstead, N.T., Civitello, D.J., and Rohr, J.R., 2015, Comparative toxicities of organophosphate and pyrethroid insecticides to aquatic macroarthropods: Chemosphere, v. 135 , p. $265-271$.

Harwood, A.D., You, J., and Lydy, M.J., 2009, Temperature as a toxicity identification evaluation tool for pyrethroid insecticides-Toxicokinetic confirmation: Environmental Toxicology and Chemistry: An International Journal, v. 28, no. 5, p. 1051-1058.

Holcombe, G.W., Phipps, G.L., and Tanner, D.K., 1982, The acute toxicity of kelthane, dursban, disulfoton, pydrin, and permethrin to fathead minnows Pimephales promelas and rainbow trout Salmo gairdneri: Environmental Pollution. Series A. Ecological and Biological, v. 29, no. 3, p. $167-178$.

Finto, K.J., 1990, Regulation by information through EPCRA: Natural Resources and Environment, v. 4, no. 3, p. 13-48.

Key, P.B., Chung, K.W., Opatkiewicz, A.D., Wirth, E.F., and Fulton, M.H., 2003, Toxicity of the insecticides fipronil and endosulfan to selected life stages of the grass shrimp (Palaemonetes pugio): Bulletin of Environmental Contamination and Toxicology, v. 70, no. 3, p. 0533-0540.

Konwick, B.J., Fisk, A.T., Garrison, A.W., Avants, J.K., and Black, M.C., 2005, Acute enantioselective toxicity of fipronil and its desulfinyl photoproduct to Ceriodaphnia dubia: Environmental Toxicology and Chemistry: An International Journal, v. 24, no. 9, p. 2350-2355. 
Lanteigne, M., Whiting, S.A., and Lydy, M.J., 2015, Mixture toxicity of imidacloprid and cyfluthrin to two non-target species, the fathead minnow Pimephales promelas and the amphipod Hyalella azteca: Archives of Environmental Contamination and Toxicology, v. 68, no. 2, p. 354-361.

Maciorowski, A., 1994, New Chemical Screen-Expedited Review for Fipronil Insecticide: EPA memorandum, p. 1-7.

Laskowski, D.A., 2002, Physical and chemical properties of pyrethroids: Reviews of Environmental Contamination and Toxicology, v. 174, p. 49-170.

Ma, J., 2005, Differential sensitivity of three cyanobacterial and five green algal species to organotins and pyrethroids pesticides: The Science of the Total Environment, v. 341, no. 1-3, p. 109-117.

Mauck, W.L., Olson, L.E., and Marking, L.L., 1976, Toxicity of natural pyrethrins and five pyrethroids to fish: Archives of Environmental Contamination and Toxicology, v. 4, no. 1, p. $18-29$.

Morolli, C., Quaglio, F., Della Rocca, G., Malvisi, J., and Di Salvo, A., 2006, Evaluation of the toxicity of synthetic pyrethroids to red swamp crayfish (Procambarus clarkii, Girard 1852) and common carp (Cyprinus carpio, L. 1758): Bulletin Francais de la Peche et de la Pisciculture, v. 380-381, p. 1381-1394.

Nimmo, D.R., Hamaker, T.L., Moore, J.C., and Sommers, C.A., 1979, Effect of diflubenzuron on an estuarine crustacean: Bulletin of Environmental Contamination and Toxicology, v. 22, no. 1, p. 767-770.

Oikari, A., Kukkonen, J., and Virtanen, V., 1992, Acute toxicity of chemicals to Daphnia magna in humic waters: The Science of the Total Environment, v. 117-118, p. 367-377.

O'Reilly, S., 2015, Assessing the toxicity of biocides on the North American signal crayfish Pacifastacus leniusculus (Dana) to aid eradication: Glasglow, Scotland, University of Glasgow, master's thesis, $172 \mathrm{p}$.

Overmyer, J.P., Rouse, D.R., Avants, J.K., Garrison, A.W., DeLorenzo, M.E., Chung, K.W., Key, P.B., Wilson, W.A., and Black, M.C., 2007, Toxicity of fipronil and its enantiomers to marine and freshwater non-targets: Journal of Environmental Science and Health. Part. B, Pesticides, Food Contaminants, and Agricultural Wastes, v. 42, no. 5, p. 471-480.

Paul, E.A., Simonin, H.A., and Tomajer, T.M., 2005, A comparison of the toxicity of synergized and technical formulations of permethrin, sumithrin, and resmethrin to trout: Archives of Environmental Contamination and Toxicology, v. 48 , no. 2 , p. 251-259.
Savitz, J.D., Wright, D.A., and Smucker, R.A., 1994, Toxic effects of the insecticide diflubenzuron (dimilin $\left.{ }^{\circledR}\right)$ on survival and development of nauplii of the estuarine copepod, Eurytemora affinis: Marine Environmental Research, v. 37, no. 3, p. 297-312.

Schleier, J.J., III, and Peterson, R.K., 2013, A refined aquatic ecological risk assessment for a pyrethroid insecticide used for adult mosquito management: Environmental Toxicology and Chemistry, v. 32, no. 4, p. 948-953.

Schlenk, D., Huggett, D.B., Allgood, J., Bennett, E., Rimoldi, J., Beeler, A.B., Block, D., Holder, A.W., Hovinga, R., and Bedient, P., 2001, Toxicity of fipronil and its degradation products to Procambarus sp.-Field and laboratory studies: Archives of Environmental Contamination and Toxicology, v. 41, no. 3 , p. 325-332.

Shanaman, L., and Carey, S., 2008, Environmental fate and ecological risk assessment of emamectin benzoate use on tree nuts and pistachios (New Use): EPA Memorandum.

Sogorb, A., Andreu-Moliner, E.S., Almar, M.M., Del Ramo, J., and Nunez, A., 1988, Temperature-toxicity relationships of fluvalinate (synthetic pyrethroid) on Procambarus clarkii (Girard) under laboratory conditions: Bulletin of Environmental Contamination and Toxicology, v. 40, no. 1, p. 13-17.

Sundaram, K.M.S., Sloane, L., and Nott, R., 1997, Adsorption and desorption kinetics of diflubenzuron and fenitrothion in two different boreal forest soils: Journal of Environmental Science and Health. Part. B, Pesticides, Food Contaminants, and Agricultural Wastes, v. 32, no. 1, p. 1-24.

Turner, L., Jacobson, S., and Shoemaker, L., 2007, Risk assessment for piscicidal formulations of antimycin: Lakewood, Washington, Compliance Services International for the Washington Department of Fish and Wildlife, p. 74.

Weston, D.P., and Jackson, C.J., 2009, Use of engineered enzymes to identify organophosphate and pyrethroid-related toxicity in toxicity identification evaluations: Environmental Science \& Technology, v. 43, no. 14, p. 5514-5520.

Weston, D.P., and Lydy, M.J., 2014, Toxicity of the insecticide fipronil and its degradates to benthic macroinvertebrates of urban streams: Environmental Science \& Technology, v. 48, no. 2 , p. $1290-1297$.

Wheelock, C.E., Miller, J., Miller, M.J., Gee, S.J., Shan, G., and Hammock, B.D., 2004, Development of toxicity identification evaluation procedures for pyrethroid detection using esterase activity: Environmental Toxicology and Chemistry, v. 23 , no. 11, p. 2699-2708. 
Wilson, J.E.H., and Costlow, J.D., 1987, Acute toxicity of diflubenzuron (DFB) to various life stages of the grass shrimp, Palaemonetes pugio: Water, Air, and Soil Pollution, v. 33 , no. $3-4$, p. $411-417$.

Wu, N., Wei, H., Shen, H., Guo, M., and Wu, T.T., 2012, Acute toxic effects of deltamethrin on red swamp crayfish, Procambarus clarkii (Decapoda, Cambaridae): Crustaceana, v. 85 , no. 8 , p. $993-1005$.

Wu, H., Gao, C., Guo, Y., Zhang, Y., Zhang, J., and Ma, E., 2014, Acute toxicity and sublethal effects of fipronil on detoxification enzymes in juvenile zebrafish (Danio rerio): Pesticide Biochemistry and Physiology, v. 115, p. 9-14.
Yang, W.C., Hunter, W., Spurlock, F., and Gan, J., 2007, Bioavailability of permethrin and cyfluthrin in surface waters with low levels of dissolved organic matter: Journal of Environmental Quality, v. 36, no. 6, p. 1678-1685.

Zhang, Z.Y., Yu, X.Y., Wang, D.L., Yan, H.J., and Liu, X.J., 2010, Acute toxicity to zebrafish of two organophosphates and four pyrethroids and their binary mixtures-Pest Management Science, formerly: Pesticide Science, v. 66, no. 1, p. 84-89. 
For additional information contact:

Director, Upper Midwest Environmental Sciences Center U.S. Geological Survey

2630 Fanta Reed Road

La Crosse, WI 54602

Publishing support provided by:

U.S. Geological Survey Science Publishing Network Indianapolis Publishing Service Center 


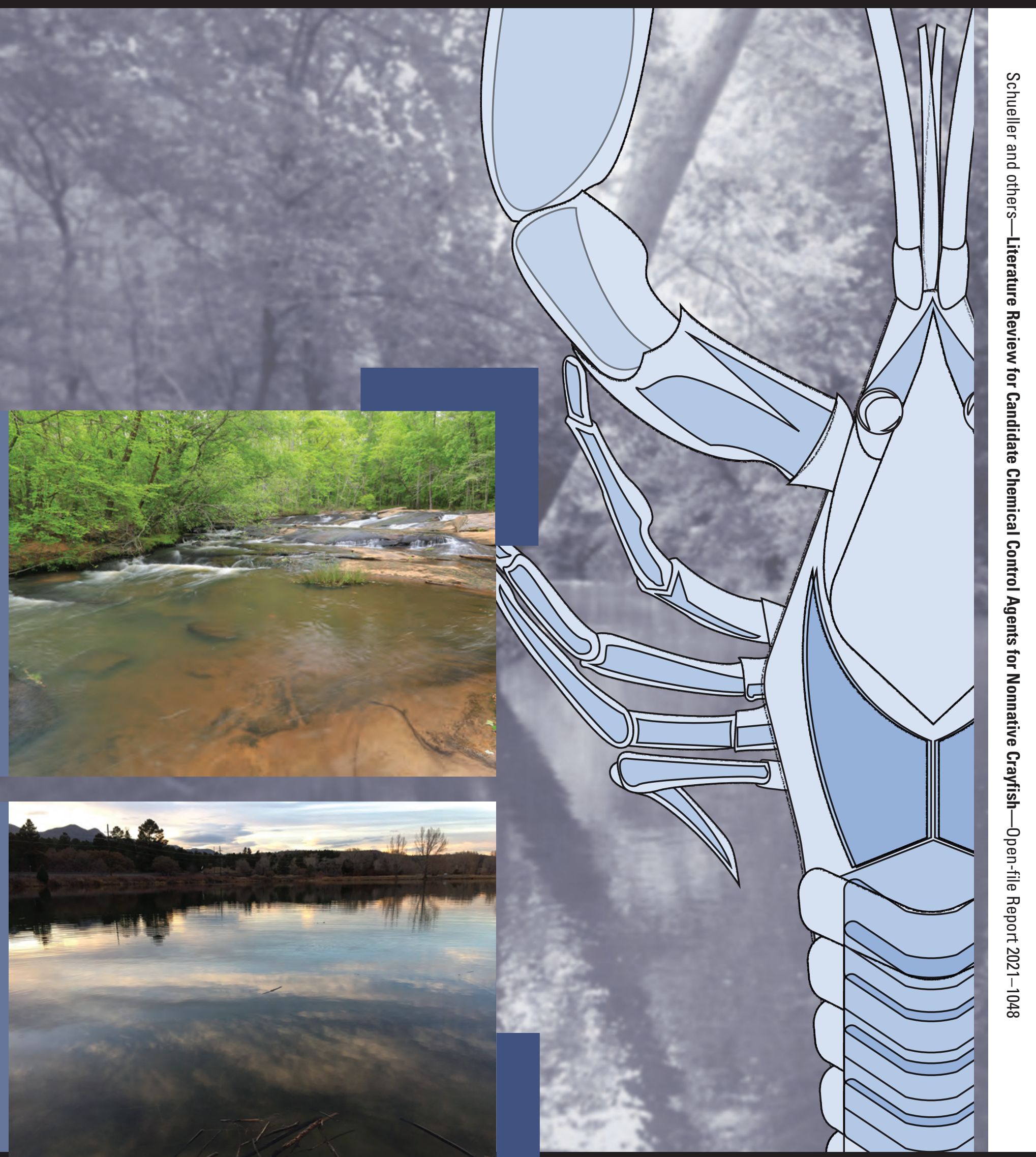

